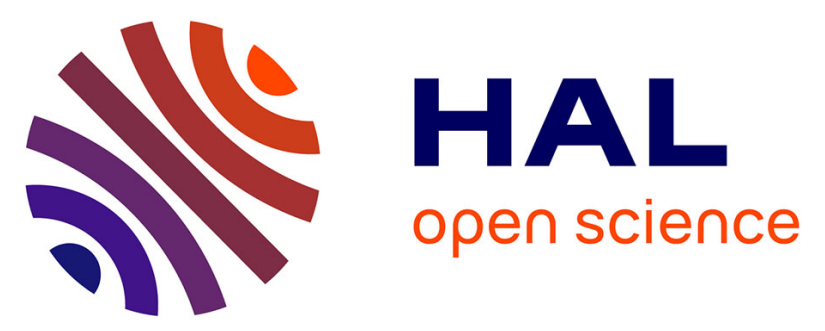

\title{
Holocene palaeohydrological changes in the northern Mediterranean borderlands as reflected by the lake-level record of Lake Ledro, northeastern Italy
}

Michel Magny, Sébastien Joannin, Didier Galop, Boris Vannière, Jean Nicolas Haas, M. Bassetti, Paolo Bellintani, Romana Scandolari, Marc Desmet

\section{To cite this version:}

Michel Magny, Sébastien Joannin, Didier Galop, Boris Vannière, Jean Nicolas Haas, et al.. Holocene palaeohydrological changes in the northern Mediterranean borderlands as reflected by the lakelevel record of Lake Ledro, northeastern Italy. Quaternary Research, 2012, 77 (3), pp.382-396. 10.1016/j.yqres.2012.01.005 . hal-00669616

\section{HAL Id: hal-00669616 https://hal.science/hal-00669616}

Submitted on 11 May 2017

HAL is a multi-disciplinary open access archive for the deposit and dissemination of scientific research documents, whether they are published or not. The documents may come from teaching and research institutions in France or abroad, or from public or private research centers.
L'archive ouverte pluridisciplinaire HAL, est destinée au dépôt et à la diffusion de documents scientifiques de niveau recherche, publiés ou non, émanant des établissements d'enseignement et de recherche français ou étrangers, des laboratoires publics ou privés. 


\title{
Holocene palaeohydrological changes in the northern Mediterranean borderlands as reflected by the lake-level record of Lake Ledro, northeastern Italy
}

\author{
Michel Magny ${ }^{\mathrm{a}, *}$, Sébastien Joannin ${ }^{\mathrm{a}}$, Didier Galop ${ }^{\mathrm{b}}$, Boris Vannière ${ }^{\mathrm{a}}$, Jean Nicolas Haas ${ }^{\mathrm{c}}$, \\ Michele Bassetti ${ }^{d}$, Paolo Bellintani ${ }^{e}$, Romana Scandolari ${ }^{f}$, Marc Desmet ${ }^{\mathrm{g}}$ \\ a Laboratoire de Chrono-Environnement, UMR 6249 du CNRS, UFR des Sciences et Techniques, 16 route de Gray, 25030 Besançon, France \\ b GEODE, UMR 5602 (CNRS), University of Toulouse 2, 5, Allées A. Machado, 31058 Toulouse, France \\ c Department of Botany, University of Innsbruck, Sternwartestrasse 15, 6020 Innsbruck, Austria \\ d CORA Ricerche Archeologiche, via Salisburgo 16, I-38100 Trento, Italy \\ e Soprintendenza per i Beni Archeologici, Provincia Autonoma di Trento, via Aosta 1, 38100 Trento, Italy \\ ${ }^{\mathrm{f}}$ Museo delle Palafitte del Lago di Ledro, Via Lungolago 1, 38060 Molina di Ledro, Italy \\ g CNRS-UMR 6113, ISTO Orléans/Tours, UFR Sciences E' Techniques, Université François Rabelais, Parc de Grandmont, F-37200 Tours, France
}

\section{A R T I C L E I N F O}

Article history:

Received 28 April 2011

Available online 17 February 2012

\section{Keywords:}

Mediterranean

Lake-level fluctuations

Lacustrine sediments

Palaeohydrology

Holocene

\begin{abstract}
A B S T R A C T
A lake-level record of Lake Ledro (northern Italy) spans the entire Holocene with a chronology derived from 51 radiocarbon dates. It is based on a specific sedimentological approach that combines data from five sediment profiles sampled in distinct locations in the littoral zone. On a millennial scale, the lake-level record shows two successive periods from 11,700 to 4500 cal yr BP and from $4500 \mathrm{cal} \mathrm{yr} \mathrm{BP}$ to the present, characterized by lower and higher average lake levels, respectively. In addition to key seasonal and inter-hemispherical changes in insolation, the major hydrological change around $4500 \mathrm{cal} \mathrm{yr}$ BP may be related to a non-linear response of the climate system to orbitally-driven gradual decrease in insolation. The Ledro record questions the notion of an accentuated summer rain regime in the northern Mediterranean borderlands during the boreal insolation maximum. Moreover, the Ledro record highlights that the Holocene was punctuated by successive centennial-scale highstands. Correlations with the Preboreal oscillation and the $8.2 \mathrm{ka}$ event, and comparison with the atmospheric ${ }^{14} \mathrm{C}$ residual record, suggest that short-lived lake-level fluctuations developed at Ledro in response to (1) final steps of the deglaciation in the North Atlantic area and (2) variations in solar activity.
\end{abstract}

(C) 2012 University of Washington. Published by Elsevier Inc. All rights reserved.

\section{Introduction}

The reconstruction of past moisture conditions and availability is of crucial interest for the understanding of Holocene environmental changes and the trajectories of societies in the Mediterranean area. Lake-level records provide independent palaeohydrological data to specify those inferred from pollen studies. However, highly resolved studies aimed specifically at lake-level reconstruction are still scarce in the Mediterranean area (Harrison and Digerfeldt, 1993; Zolitschka et al., 2000; Reed et al., 2001; Giraudi et al., 2011). In addition, correlations and comparisons between records on an inter-regional scale require lake-level data based on a robust chronology and, preferably, obtained from similar proxies.

Recently, in a thorough review of outstanding issues on Mediterranean palaeoenvironmental conditions, P.C. Tzedakis (2007) has pointed out the increasingly complex paleohydrological/climatic scenarios outlined to reconcile conflicting data and/or interpretations, and he has

\footnotetext{
* Corresponding author.

E-mail address: michel.magny@univ-fcomte.fr (M. Magny).
}

questioned the notion of an accentuated summer rain regime in the northern Mediterranean borderlands during the boreal insolation maximum. At the same time, lake-level studies at Lake Accesa in north-central Italy have given evidence of a well-marked lake-level lowstand during the mid-Holocene (Magny et al., 2007). The Accesa lake-level record clearly contrasts with the maximal highstands of lake levels reconstructed at a more southerly latitude in the central Mediterranean (Sadori and Narcisi, 2001) and in the eastern Mediterranean (Digerfeldt et al., 2007; Eastwood et al., 2007). Such observations in the central Mediterranean seem to be in agreement with a tri-partition of western Europe as inferred from a comparison of palaeohydrological records with drier conditions over the mid-European latitudes between ca. $50^{\circ}$ and $43^{\circ} \mathrm{N}$, and wetter conditions over the northern and southern Europe (Magny et al., 2003, 2011).

As a further contribution to the reconstruction of Holocene hydroclimatic conditions in the central Mediterranean, this paper presents a high-resolution lake-level record established at Lake Ledro in northeastern Italy at the northern edge of the Mediterranean area. An earlier paper (Magny et al., 2009a) focused on the reconstruction of lakelevel changes at Lake Ledro during the late Holocene (last $4000 \mathrm{yr}$ ), and on problems relative to the development of settlements in 
humid areas of northern Italy during the Bronze Age. This study (1) presents the results of supplementary cores and sediment profiles, and (2) combines these new data with earlier ones to establish a lake-level record for the entire Holocene at Lake Ledro.

Site and methods

Lake Ledro $\left(45^{\circ} 87^{\prime} \mathrm{N}, 10^{\circ} 76^{\prime} \mathrm{E}, 652 \mathrm{~m}\right.$ a.s.l. $)$ is a relatively small lake (2.8 km long, $0.8 \mathrm{~km}$ wide, $38 \mathrm{~m}$ maximum depth) located on the southern slope of the Alps (Fig. 1). The lake surface is ca. $2.17 \mathrm{~km}^{2}$. The outlet of Lake Ledro is the Ponale River, which is responsible for downcutting in a morainic dam (Beug, 1964). In 1929, the outlet was transformed for hydroelectricity and artificial regulation of the water table. Consequently, large parts of the original natural outlet area were disturbed and today the outlet itself is most often dry. The lake is surrounded by mountains culminating at ca. $1500-2200 \mathrm{~m}$ a.s.l. The catchment area covers ca. $131 \mathrm{~km}^{2}$ and is characterized by relatively steep slopes, and by a carbonate substratum with Triassic (dolomite), Jurassic and Cretaceous limestone.

Lake Ledro is very close to the northern extremity of Lake Garda ( $65 \mathrm{~m}$ a.s.l.). Due to the influence of a large body of water, the region of Lake Garda ( $65 \mathrm{~m}$ a.s.l.) is famous for particularly mild climatic conditions which allow the presence of Mediterranean species (Fig. 1; Beug, 1964). However, due to higher altitude, the vegetation in the Ledro Valley is dominated by Fagus sylvatica (beech) mixed with Abies alba (silver fir), then Picea abies (spruce) in the higher part of the montane belt (650-1600 m), and by Pinus mugo (mountain pine), Alnus viridis (green alder), Larix decidua (larch) and Picea in the subalpine belt (1600-2000 m). Above $2000 \mathrm{~m}$ a.s.l. grasslands dominate (Beug, 1964; Reisigl, 2001). Generally speaking, mixed oak forests do not develop in the Ledro Valley. At Molina di Ledro, the mean temperature is ca. $0^{\circ} \mathrm{C}$ in the coldest month (January) and ca. $20^{\circ} \mathrm{C}$ in the warmest month (July). The annual precipitation ranges from ca. 750 to ca. $1000 \mathrm{~mm}$, with seasonal maxima in spring and autumn.

In addition to previous lake-level data (Magny et al., 2009a) obtained from the stratigraphic section of site Ledro I and from core Ledro II-1 (Fig. 1), the present study examines three new sediment profiles recently sampled on the south-eastern shores of Lake Ledro (Fig. 1) and of particular interest for the reconstruction of Holocene lake-level fluctuations:

- Site Ledro II is located on the northeastern shore of the lake (Fig. 1, panel B). Core Ledro II-3 was taken with a Russian peat corer. It provides a ca. 8-m-long sediment sequence mainly composed of carbonate lake-marl. It continuously documents the early to mid-Holocene, and it completes the late Holocene data obtained from core Ledro II-1 (Magny et al., 2009a ; Fig. 1, panel C).

- Site San Carlo. Rescue archaeological excavations provoked by works for the reinforcement of building foundations close to Hotel San Carlo, offered the opportunity to sample a 1.6-m-high stratigraphic section above the present-day lowered water-level. Overlying morainic deposits and a pebble beach formation, the sediment sequence observed along a ca. 11-m section highlights an alternation of different layers composed of carbonate lakemarl, oncolites, and peaty sediments. It also includes an organic Bronze Age archaeological layer.

- Site Ponale. In 2008, we initiated the digging of a ca. 5-m-long trench across the past outlet of Lake Ledro, i.e. a key site for the reconstruction of Holocene lake-level changes. A 2.7-m-high stratigraphic section was recognised and sampled. It showed an alternation of carbonate lake marl, gyttja, and peat layers overlying late-glacial gravels and pebbles.

The absolute elevation (in metres a.s.l.) of the sediment profiles studied at Ledro was established in the field by reference to that of the daily water table furnished by the private company Hydro Dolomiti Enel.

Sedimentological analyses for lake-level reconstruction have been carried out on the three sediment profiles of San Carlo, Ponale, and core Ledro II-3, and palynological analyses only on the profile of Ponale. An additional high-resolution pollen record has been established from core LLO81 (Fig. 1) taken in the profundal zone of Lake Ledro where sediment accumulation is not affected by littoral erosion and sediment hiatuses. Pollen preparation followed standard methods using treatment with $\mathrm{HCL}, 10 \% \mathrm{KOH}, \mathrm{HF}$, acetolysis and final mounting in glycerine. More than 450 terrestrial pollen grains were counted for each sample. Cyperaceae, palustrine taxa, aquatics and spores are systematically excluded from the pollen sum. All pollen types are defined according to Faegri and Iversen (1989), although some identification require the use of a pollen atlas (Reille, 1992-1998). A detailed reconstruction of the vegetation history is beyond the scope of the present study and will be developed in a further more specific paper.

The changes in lake level were reconstructed using a specific technique described in detail and validated elsewhere (Magny, 1992, $1998,2004,2006)$. It is based on a sedimentological approach that combines several markers as follows:

- The grain-size analysis : coarser deposits correspond to nearshore areas (shallower water and higher hydrodynamics). The grain-size analysis has been carried out by sieving. The percentages indicated on the diagrams of Figures 2, 3, and 4 refer to weight percentage.

- The lithology: silty carbonate lake-marl is deposited in lake water, whereas organic deposits (coarse gyttja, peat, anmoor) reflect nearshore areas (eulittoral zone, littoral mire).

- The macroscopic components of lake marl: it has been shown (Magny 1992, 1998, 2004, 2006) that, in carbonate lakes, the coarser fractions (larger than $0.2 \mathrm{~mm}$ ) of lake marl are mainly composed of (1) carbonate concretions of biochemical origin, (2) mollusc tests, and (3) plant macro-remains. The concretions can be divided into several morphotypes. Modern analogue studies demonstrated that, in the fraction $>0.5 \mathrm{~mm}$, each morphotype shows a specific spatial distribution from the shore to the extremity of the littoral platform, with the successive domination of oncolites (nearshore areas with shallow water and a high-energy environment), cauliflower-like forms (littoral platform), plate-like concretions (encrustations of leaves from the Potamogetonion and Nymphaeion belts), and finally tube-like concretions (stem encrustations from the Characeae belt on the platform slope). In addition to variations in the assemblages of carbonate concretions, modern analogues studies also demonstrated that the relative frequency of plant macroremains and mollusc shells provide further information about the deposition environment. The abundance of mollusc shells increases towards the shore (Mouthon, 1984) as do vegetal remains partly inherited from littoral vegetation and mires (particularly lignosous vegetal remains and anmoor particles). After wet sieving, the macroscopic components of fraction $>0.5 \mathrm{~mm}$ were identified and counted using a binocular microscope.

- Erosion surfaces (sediment hiatuses) marked by (1) pebblebeach accumulation (reduction horizon), (2) unconformities between sediment layers (Mitchum et al., 1977), and (3) abrupt changes in the sedimentological diagram point to a lowering of the limit of the sediment deposition associated with a lowering of the lake level. As extensively explained by Digerfeldt $(1986,1988)$, a raised limit of sediment accumulation gives evidence of a rise in lake level.

The chronology is based on 51 AMS radiocarbon dates (12 from site San Carlo, 13 from site Ponale, 12 from core Ledro II-3, 8 from site Ledro I, and 6 from core Ledro II-1; Table 1) from terrestrial plant macro-remains or from littoral peat deposits. Possible disturbances due to reworking material cannot be excluded in littoral areas marked by high hydrodynamics. However, the radiocarbon data set established for lake-level studies at Ledro offers a solid support to correlations between the analysed sediment profiles. The ages have been calibrated referring to Stuiver et al. (1998) and Reimer et al. (2004). 


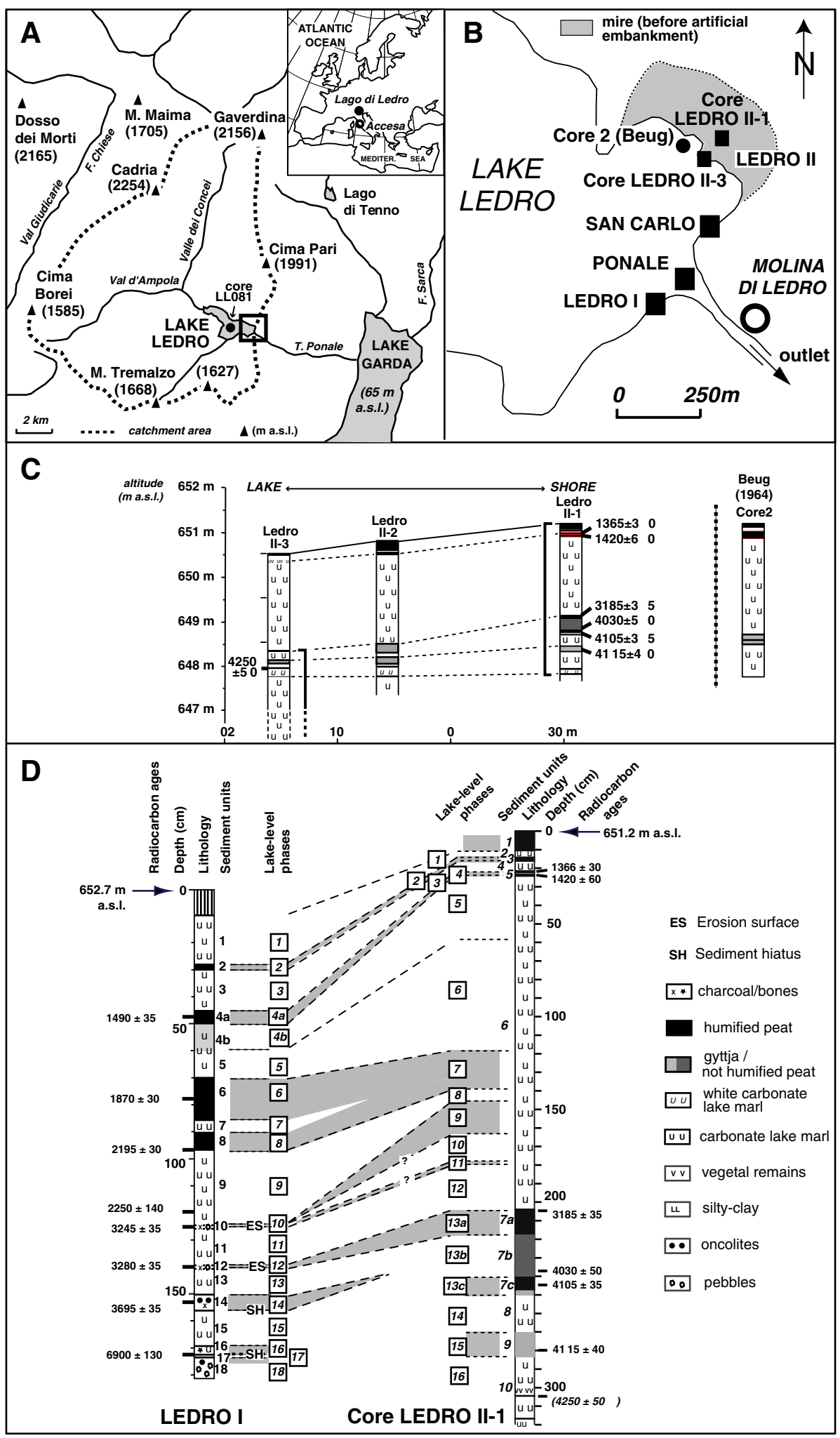

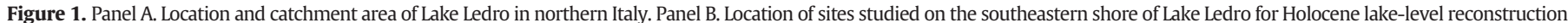

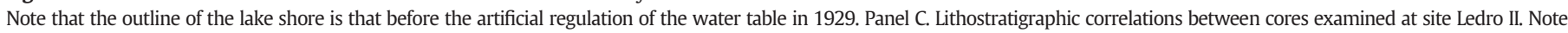

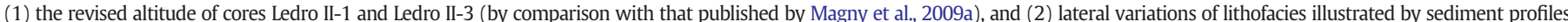

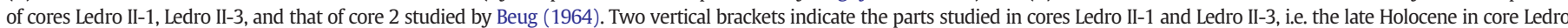

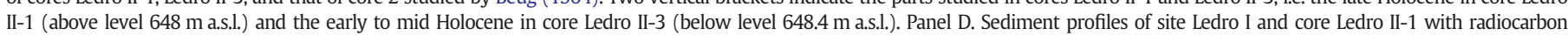
dates and reconstructed lake-level phases (Magny et al., 2009a). ES: erosion surface; SH: sediment hiatus. Note that all dates are reported as ${ }^{14} \mathrm{C}$ yr BP. 


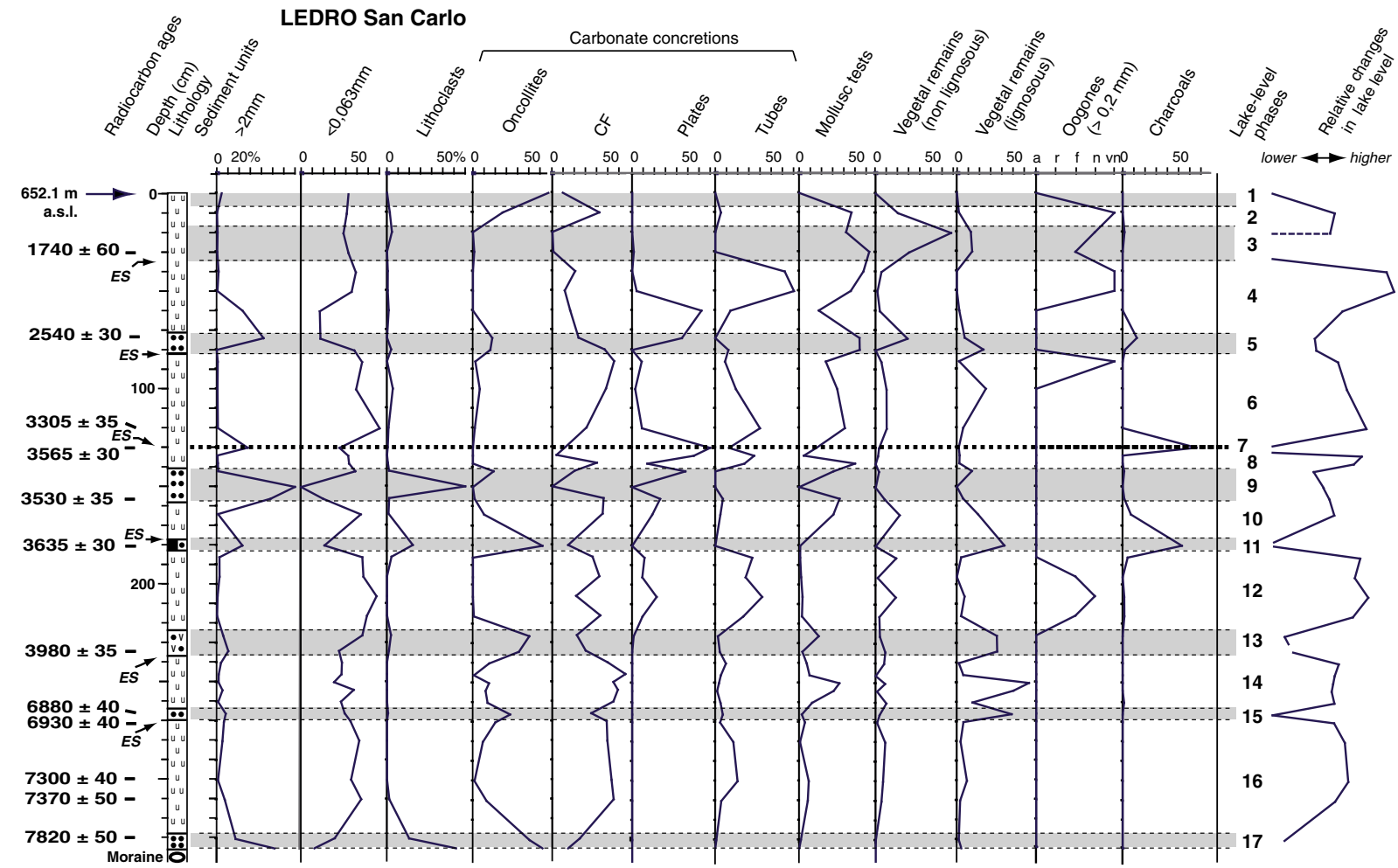

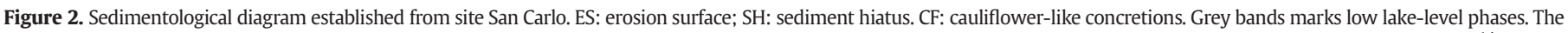

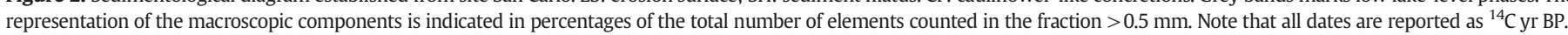

\section{Results}

In the following sections are presented lake-level data obtained from the sediment profiles of sites San Carlo, Ponale, and core Ledro II-3. The sediment diagrams in Figures 2, 3, and 4 show the representation of macroscopic components in fraction $>0.5 \mathrm{~mm}$; it is expressed in percentages by reference to the total number of elements counted per sample. On the right hand side of the sediment diagrams (Fig. 2, 3, and 4), a curve of relative changes in lake level indicates the ratio between the total scores (i.e., addition of percentages) of possible indicators marking low lake-level conditions (e.g., oncolites, cauliflower-type concretions, vegetal macro-remains), and those marking high lake-level conditions (e.g., plate and tube concretions; Magny, 1992, 1998, 2006). In a first approximation, the curves of relative changes in lake level provide qualitative data to distinguish successive phases of high and low water table registered by each sediment core. In a second phase (see below, section 'A synthetic lake-level curve'), a comparison of the lake-level data provided by these three sites and those obtained from site Ledro I and core Ledro II-1 (see Fig. 1, panel D) allows reconstruction of a quantitative synthetic lakelevel curve at Ledro for the Holocene with absolute elevation of past lake levels.

\section{Site San Carlo}

Figure 2 shows the sediment diagram established from the stratigraphic section of site San Carlo. The chronology is based on 12 radiocarbon dates (Table 1, Fig. 2). This sediment sequence appears to have been affected by several sediment hiatuses and erosion surfaces because of (1) its relatively high elevation, which makes the site more sensitive to past lake-level lowstands (lowering of the sedimentation limit; Digerfeldt, 1988). The diagram gives evidence of 17 distinct successive phases of high and low water table, as follows (Fig. 2).

On top of the basal morainic deposits, a pebble beach layer with oncolites is observed and marks lake-shore sedimentation. This phase (17) developed around $7820 \pm 50{ }^{14} \mathrm{C}$ yr BP $(8764-8455$ cal yr BP). A rise in lake level (phase 16) provoked the sedimentation of a first carbonate lake-marl layer, which overlies the morainic deposits. Afterwards, the sediment sequence San Carlo reveals 8 successive phases of low lake level marked by peaks of oncolites, lithoclasts (terrestrial inputs), and coarser texture (phases 15, 13, 11, 9, 7, 5, 3 and 1). Phase 11 also corresponds to the formation of an organic archaeological layer dated to the Early Bronze Age. Unconformities between sediment layers highlight the development of erosion surfaces during phases 15 , $11,7,5$, and 3 , while the stratigraphic section gives evidence of important sediment hiatuses with an absence of Holocene sediments before $7820 \pm 50{ }^{14} \mathrm{C}$ yr BP (8764-8455 cal yr BP) and an accumulation of less than 30 -cm-thick sediment layer between $6880 \pm 40{ }^{14} \mathrm{C}$ yr BP (7818-7621 cal yr BP) and $3980 \pm 35{ }^{14} \mathrm{C}$ yr BP (4529-4300 cal yr BP). Intermediate phases $14,12,10,8,6,4$, and 2 correspond to higher lake-levels marked by the accumulation of carbonate lake-marl with a finer texture, the development of plate and tube concretions, and a decline of oncolites. The curve of charcoals shows two large peaks during phases 11 and 7, and a smaller one during phase 5, which confirm or suggest possible increases in wildfires and/or the proximity of human settlements, as marked by the archaeological layer of phase 11 dated to $3635 \pm 30{ }^{14} \mathrm{C}$ yr BP (4081-3861 cal yr BP; Early and Middle Bronze Age). The upper part of the stratigraphic section was disturbed by anthropogenic embankment.

Site Ponale

Both pollen and sediment analyses (Fig. 3 ) have been carried out from the stratigraphic section Ponale, discovered by excavations in the past outlet of Lake Ledro (Ponale River). The Ponale sediment profile is located between 648.3 and $651 \mathrm{~m}$ a.s.l., i.e. at an elevation generally lower than that of the San Carlo sediment sequence (Fig. 2). The chronology is based on 13 radiocarbon dates (Table 1 ). The basal layer (sediment unit 25) is composed mainly of pebbles and oncolites. The radiocarbon date provided by vegetal macro-remains from level 648.28 m a.s.l. $\left(11,050 \pm 60{ }^{14} \mathrm{C}\right.$ yr BP, $13,104-12,732 \mathrm{cal}$ yr BP) as well as the high percentage of Non-Arboreal Pollen (NAP) and Artemisia 

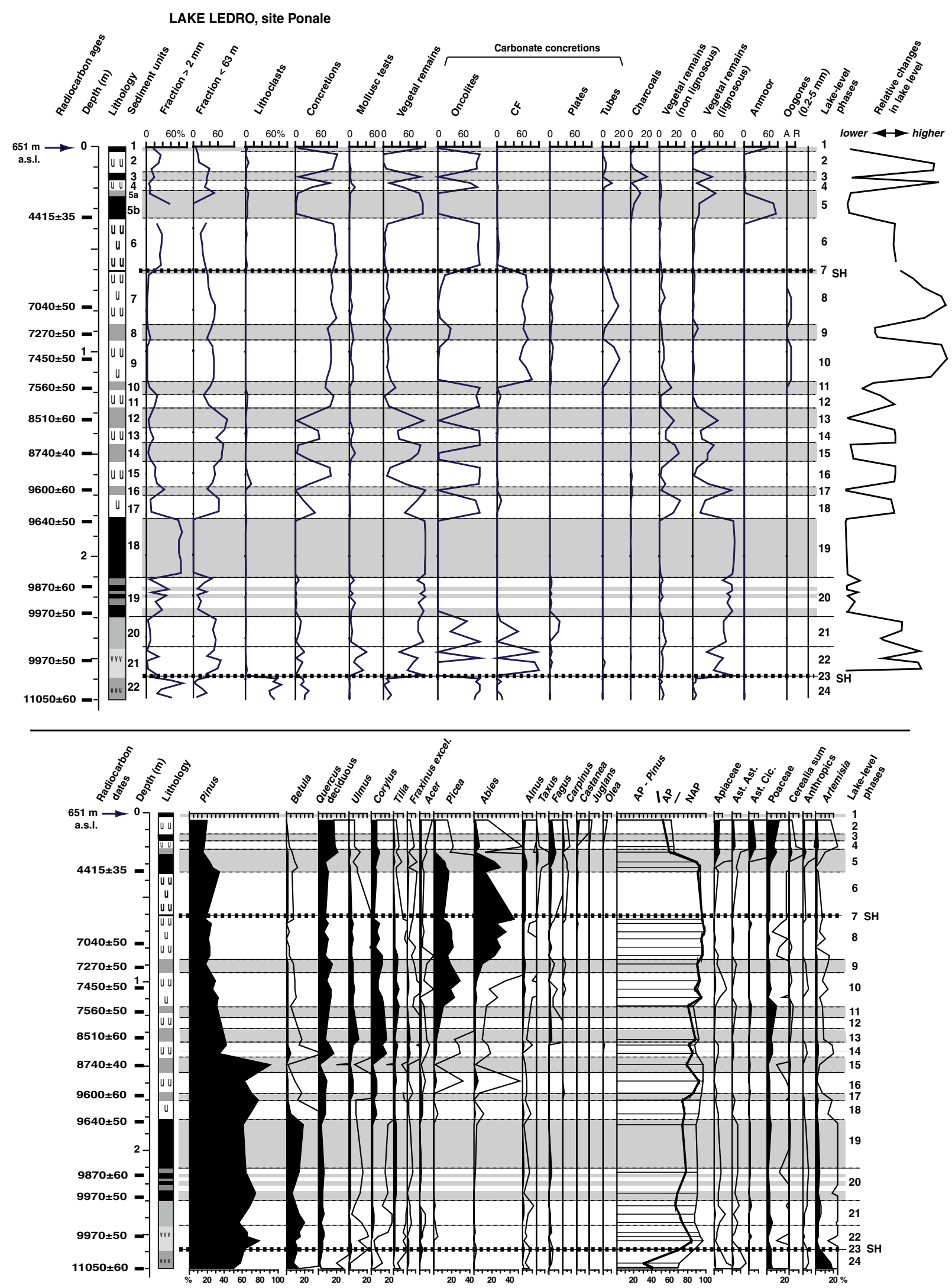

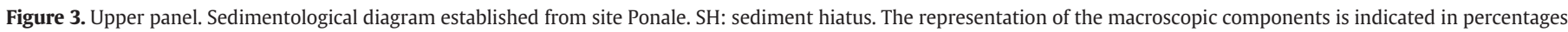

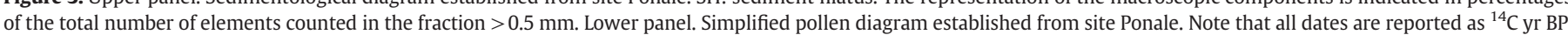

suggest Younger Dryas deposits (Beug, 1964). Abrupt jumps in the representation of lithoclasts, oncolites, $\mathrm{CF}$ concretions and vegetal remains at the transition between sediment units 22 and 21 point to a sediment hiatus (lake-level lowering, phase 23). It coincides with a rapid decrease in the curve of Artemisia (Younger Dryas/Holocene transition). Afterwards, the sediment units 21 to 17 show an alternation of carbonate 


\section{Core Ledro II-3}
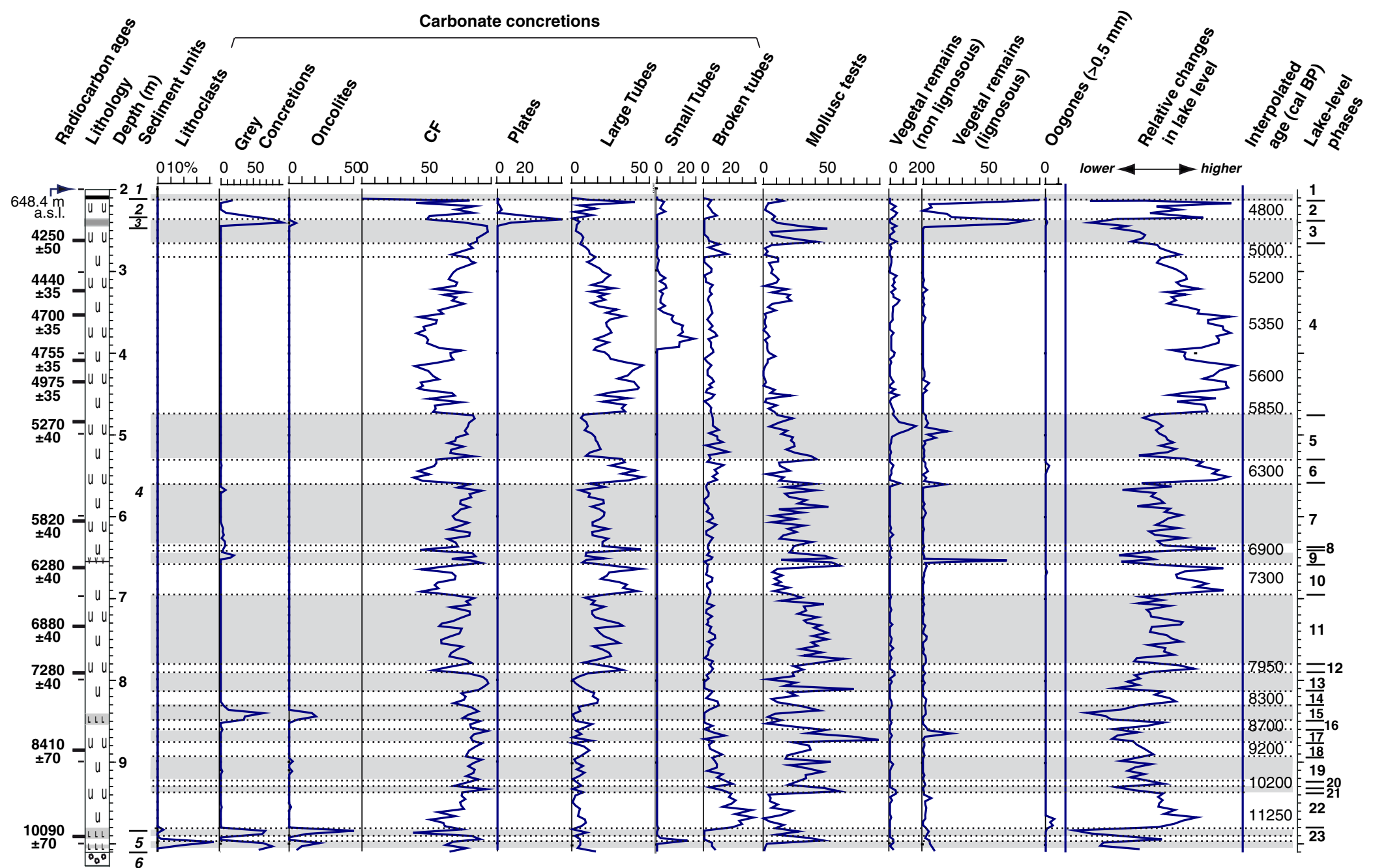
Table 1

Radiocarbon dates obtained from the Ledro sediment profiles. Age calibration was done using the data sets by Stuiver et al. (1998) and Reimer et al. (2004).

\begin{tabular}{|c|c|c|c|c|c|c|}
\hline Site and core & Depth in core $(\mathrm{cm})$ & Radiocarbon date $\left({ }^{14} \mathrm{C}\right.$ yr BP $)$ & Calibrated age ( 2 sigmas) & Laboratory reference & Material & Number in Table 2 \\
\hline \multirow[t]{8}{*}{ Ledro I } & $47-48$ & $1490 \pm 35$ & 1509-1304 cal yr BP & Poz-11068 & Charcoal + bark & 1 \\
\hline & $77-88$ & $1870 \pm 30$ & $1877-1724$ cal yr BP & Poz-11069 & Wood fragments & 2 \\
\hline & $97-98$ & $2195 \pm 30$ & 2317-2131 cal yr BP & Poz-11070 & Wood fragments & 3 \\
\hline & $119-120$ & $2250 \pm 140$ & 2707-1934 cal yr BP & Poz-13143 & Charcoal & 4 \\
\hline & $125-126$ & $3245 \pm 35$ & 3559-3392 cal yr BP & Poz-11893 & Charcoal + bark & 5 \\
\hline & $140-142$ & $3280 \pm 35$ & 3610-3406 cal yr BP & Poz-11894 & Charcoal & 6 \\
\hline & $152-153$ & $3695 \pm 35$ & 4149-3927 cal yr BP & Poz-11072 & Charcoal & 7 \\
\hline & $172-173$ & $6900 \pm 130$ & 7972-7514 cal yr BP & Poz-13144 & Charcoal & 8 \\
\hline \multicolumn{7}{|l|}{ Ledro II } \\
\hline \multirow{6}{*}{$\begin{array}{l}\text { Core Ledro } \\
\text { II-1 }\end{array}$} & $21-22$ & $1365 \pm 35$ & 1339-1189 cal yr BP & Poz-17035 & Peat & 9 \\
\hline & $23-24$ & $1420 \pm 60$ & $1507-1184$ cal yr BP & Poz-18588 & Peat & 10 \\
\hline & 204-205 & $3185 \pm 35$ & 3470-3356 cal yr BP & Poz-17036 & Twigs & 11 \\
\hline & $236-237$ & $4030 \pm 50$ & $4805-4413$ cal yr BP & Poz-18596 & Peat & 12 \\
\hline & $244-245$ & $4105 \pm 35$ & $4816-4453$ cal yr BP & Poz-17038 & Peat & 13 \\
\hline & $280-281$ & $4115 \pm 40$ & $4822-4524$ cal yr BP & Poz-17039 & Twigs & 14 \\
\hline \multirow{12}{*}{$\begin{array}{l}\text { Core Ledro } \\
\text { II-3 }\end{array}$} & 264 & $4250 \pm 50$ & $4960-4590$ cal yr BP & Poz-21190 & Wood & 15 \\
\hline & 325 & $4440 \pm 35$ & $5282-4878$ cal yr BP & Poz-21191 & Wood & 16 \\
\hline & 366 & $4700 \pm 35$ & 5581-5321 cal yr BP & Poz-21193 & Wood + leaves & 17 \\
\hline & 416 & $4755 \pm 35$ & 5588-5331 cal yr BP & Poz-21194 & Wood & 18 \\
\hline & 444 & $4975 \pm 35$ & $5862-5608$ cal yr BP & Poz-21195 & Leaves & 19 \\
\hline & 512 & $5270 \pm 40$ & 6182-5935 cal yr BP & Poz-21197 & Leaves & 20 \\
\hline & 622 & $5820 \pm 40$ & 6731-6504 cal yr BP & Poz-21198 & Wood & 21 \\
\hline & 674 & $6280 \pm 40$ & $7309-7030$ cal yr BP & Poz-21199 & Wood & 22 \\
\hline & 758 & $6880 \pm 40$ & $7818-7621$ cal yr BP & Poz-21200 & Wood & 23 \\
\hline & 814 & $7280 \pm 40$ & 8175-8014 cal yr BP & Poz-21201 & Wood & 24 \\
\hline & 915 & $8410 \pm 70$ & 9537-9267 cal yr BP & Poz-21202 & Wood & 25 \\
\hline & 1019 & $10090 \pm 70$ & $11982-11342$ cal yr BP & Poz-21204 & Wood & 26 \\
\hline \multirow[t]{12}{*}{ Site San Carlo } & 15 & $1740 \pm 60$ & 1816-1534 cal yr BP & Poz-27896 & Wood & 27 \\
\hline & 30 & $2540 \pm 30$ & $2747-2496$ cal yr BP & Poz-27898 & Charcoal & 28 \\
\hline & 60 & $3305 \pm 35$ & $3630-3463$ cal yr BP & Poz-28965 & Charcoal & 29 \\
\hline & 65 & $3565 \pm 30$ & $3970-3727$ cal yr BP & Poz-27899 & Charcoal & 30 \\
\hline & 78 & $3530 \pm 35$ & 3897-3702 cal yr BP & Poz-28966 & Charcoal & 31 \\
\hline & 90 & $3635 \pm 30$ & 4081-3861 cal yr BP & Poz-27900 & Charcoal & 32 \\
\hline & 117 & $3980 \pm 35$ & $4529-4300$ cal yr BP & Poz-27901 & Wood & 33 \\
\hline & 133 & $6880 \pm 40$ & 7818-7621 cal yr BP & Poz-27902 & Wood & 34 \\
\hline & 135 & $6930 \pm 40$ & $7848-7676$ cal yr BP & Poz-28967 & Wood + charcoal & 35 \\
\hline & 148 & $7300 \pm 40$ & $8181-8020$ cal yr BP & Poz-28969 & Wood & 36 \\
\hline & 153 & $7370 \pm 50$ & $8308-8060$ cal yr BP & Poz-27903 & Wood & 37 \\
\hline & 163 & $7820 \pm 50$ & $8764-8455$ cal yr BP & Poz-28970 & Wood & 38 \\
\hline \multirow[t]{13}{*}{ Site Ponale } & 33 & $4415 \pm 35$ & $5280-4860$ cal yr BP & Poz-32257 & Wood & 39 \\
\hline & 74 & $7040 \pm 50$ & $7970-7750$ cal yr BP & Poz-32258 & Wood & 40 \\
\hline & 89 & $7270 \pm 50$ & $8180-7983$ cal yr BP & Poz-30733 & Wood & 41 \\
\hline & 104 & $7450 \pm 50$ & $8371-8183$ cal yr BP & Poz-32259 & Wood & 42 \\
\hline & 118 & $7560 \pm 50$ & $8450-8210$ cal yr BP & Poz-32260 & Wood & 43 \\
\hline & 134 & $8510 \pm 60$ & 9580-9415 cal yr BP & Poz-33877 & Wood & 44 \\
\hline & 146 & $8740 \pm 40$ & 9890-9560 cal yr BP & Poz-32261 & Charcoal & 45 \\
\hline & 168 & $9600 \pm 60$ & $11170-10747$ cal yr BP & Poz-33878 & Wood & 46 \\
\hline & 184 & $9640 \pm 50$ & $11192-10781 \mathrm{cal} \mathrm{yr}$ BP & Poz-30735 & Wood & 47 \\
\hline & 216 & $9870 \pm 60$ & $11600-11183$ cal yr BP & Poz-33880 & Wood & 48 \\
\hline & 227 & $9970 \pm 60$ & $11700-11240$ cal yr BP & Poz-32262 & Charcoal & 49 \\
\hline & 250 & $9970 \pm 60$ & $11700-11240$ cal yr BP & Poz-32263 & Charcoal & 50 \\
\hline & 272 & $11050 \pm 60$ & $13104-12732$ cal yr BP & Poz-30736 & Wood & 51 \\
\hline
\end{tabular}

lake-marl, coarse gyttja and peaty layers, which mark an unstable water table and rapid successive changes in lake level between $9970 \pm 50$ ${ }^{14} \mathrm{C}$ yr BP $\left(11,700-11,240\right.$ cal yr BP) and $9600 \pm 60{ }^{14} \mathrm{C}$ yr BP $(11,710-$ $10,747 \mathrm{cal}$ yr BP). The radiocarbon ages obtained from sediment units 21 to 16 suggest a relatively high sedimentation rate with an important accumulation of coarse gyttja-peaty deposits during the lowstands and carbonate lake-marl during highstands. Lake-level phase 21 appears to have been synchronous with a slight reinforcement of Artemisia values.

Sediment units 16 to 8 are characterized by an alternation of gyttja layers which accumulated during phases of lower lake level (phases $17,15,13,11$, and 9), and carbonate lake-marl layers which formed during phases of higher lake level (phases 16, 14,12, and 10). It is worth noting that sediment units 9 and 7 show a strong development of $\mathrm{CF}$ and tube concretions, which clearly contrasts with the domination of oncolites in the underlying and overlying sediment units. This marks important rises in lake level during phases 10 and 8. In addition, both phases 10 and 8 coincided with the successive expansion of Picea and Abies respectively, while preceding less-pronounced highstands (phases 18,16, and 14) were synchronous with small peaks of Picea and Abies.

The abrupt jump of the curves of $\mathrm{CF}$ and oncolites at the transition between the sediment units 7 to 6 in addition to the radiocarbon ages obtained from sediment units $8\left(7270 \pm 50{ }^{14} \mathrm{C} \mathrm{yr} \mathrm{BP}\right.$, $8180-7983$ cal yr BP) and the base of sediment unit 5 (4415 \pm 35 ${ }^{14} \mathrm{C}$ yr BP, 5280-4860 cal yr BP) suggests a sediment hiatus between lake-level phases 8 and 6 . All together, sediment units 6 to 1 show an alternation of low lake levels (phases 5,3 , and 1 ) marked by the deposition of gyttja, peat and anmoor, and higher lake-levels (phases 6, 4, and 2) recorded by carbonate lake-marl where oncolites dominate. In a previous study (Shotton et al., 1968), sediment unit 3 (equivalent to lake-level phase 3) has been dated to $3656 \pm 66$ and $3642 \pm 36{ }^{14} \mathrm{C} \mathrm{yr}$ $\mathrm{BP}$. In the pollen diagram, sediment unit $5 \mathrm{a}$ composed of gyttja corresponds to a development of Cerealia and anthropogenic indicators as well as a rapid decline of arboreal pollen (Early Bronze Age settlement). 
Finally, the last $3500 \mathrm{yr}$ are not documented at site Ponale probably because of disturbances due to past successive archaeological excavations in the outlet area (e.g., Battaglia, 1943).

Core Ledro II-3

Figure 4 shows the sediment diagram established from the middle and lower parts of core Ledro II-3. The upper part may be considered to be documented by core Ledro II-1 (Fig. 1; Magny et al., 2009). This sequence is composed of 6 sediment units. Above a basal pebble layer (sediment unit 6), a silty-clayish lake marl (sediment unit 5) is overlaid by a ca. 7.7-m-thick carbonate lake-marl layer which forms the relatively homogeneous sediment unit 4 . The upper part of the profile displays a carbonate lake-marl layer (sediment unit 2) interbedded between a gyttja and a peat layer (sediment units 3 and 1 respectively). Lithostratigraphic correlations indicate that sediment units 3, 2, and 1 in core Ledro II-3 correspond to sediment units 9, 8, and 7 of core Ledro II-1 (Fig. 1; Magny et al., 2009a). The chronology is based on 12 radiocarbon dates in addition to two others inferred from lithostratigraphic correlations with the neighbouring core Ledro II-1 (Magny et al., 2009a).

On a millennial scale, the sedimentological indicators suggest a first period spanning the early Holocene until ca. $7280 \pm 40{ }^{14} \mathrm{C} \mathrm{yr}$ BP (8175-8014 cal yr BP), characterized by lower lake-level conditions with a strong domination of CF concretions and a weak representation of tube concretions. Afterwards, the second period until ca. 5900 cal yr BP shows the development of the tube concretions around an average value of ca. $20-30 \%$, while the representation of CF concretions retreats from ca $80-90 \%$ to ca. $70 \%$. This suggests a slight increase in the water table. A third period until ca. $5250 \mathrm{cal} \mathrm{yr}$ $\mathrm{BP}$ coincided with a marked rise in the lake level as indicated by a clear decline of $\mathrm{CF}$ concretions, an important development of the tube concretions, and a strong retreat of the mollusc tests. Finally, a fourth period until ca. 4700 cal yr BP corresponds to a trend towards lowering, with a clear reinforcement of the CF concretions and mollusc tests, a retreat of tube concretions, and the formation of littoral lithofacies (gyttja and peat deposits) of sediment units 3 and 1 respectively. This lowering period was interrupted around $4800 \mathrm{cal} \mathrm{yr}$ BP by a rise event marked by peaks of plate and tube concretions (lake-level phase 2, Fig. 4).

On a centennial scale, the curve of the relative changes in lake-level on the right hand of the diagram (Fig. 4) shows that the beginning of the Holocene coincided with low water-table conditions well marked by peaks of oncolites and grey concretions. Afterwards, the curve suggests that the Holocene was punctuated by successive highstands around $11,500-11,000,10,200,9200,8700,8300,7950,7300-7100,6900,6300$, $5850,5600,5350,5200,5000$, and $4800 \mathrm{cal} \mathrm{yr} \mathrm{BP}$. It is noteworthy that those dated to $11,400-11,300,7300-7100,6300,5850-5300$, and 4800 cal yr BP appear to be major events within these successive events.

A synthetic lake-level curve

A synthetic absolute curve of Holocene lake-level fluctuations for Lake Ledro was established using a two-step strategy (Magny et al., 2007). In the first step, curves of relative changes in lake level are constructed from the sediment diagrams as shown above by the curves on the right-hand side of the diagrams in Figures 2, 3, and 4, and in Panel D in Figure 1 (see also upper panel of Fig. 6). The second step has two aims:

(1) To establish a synthetic lake-level record for the Holocene at Lake Ledro. This curve presents a synthesis of all events distinguished from the 5 sediment profiles studied at Ledro. It is based on the correlations and radiocarbon dates presented in Table 2 and in the upper panel of Figure 6. Table 2 also gives evidence of how the age and duration of the important sediment hiatuses recognized in the Ponale, San Carlo and Ledro I sediment sequences have been inferred from available radiocarbon ages and correlations between sediment profiles.

(2) To quantify the magnitude of successive lake-level fluctuations.

The estimation of the past positions of the water table (expressed in absolute elevation in meters a.s.l.; Fig. 6, lower panel) and,
Table 2

Correlations between lake-level phases distinguished in the 5 sediment profiles studied at Lake Ledro. The numbers in bold type refer to lake-level phases (see Figs. 1, 2, 3, and 4; see also upper panel of Fig. 6), while the numbers in brackets refer to radiocarbon ages listed in Table 1. Asterisk: note that sediment unit 3 of the Ponale sediment sequence (equivalent to lake-level phase 3; Figs. 3 and 6) was dated to $3656 \pm 66$ and $3642 \pm 42{ }^{14} \mathrm{C}$ yr BP in a previous study (Shotton et al., 1968).

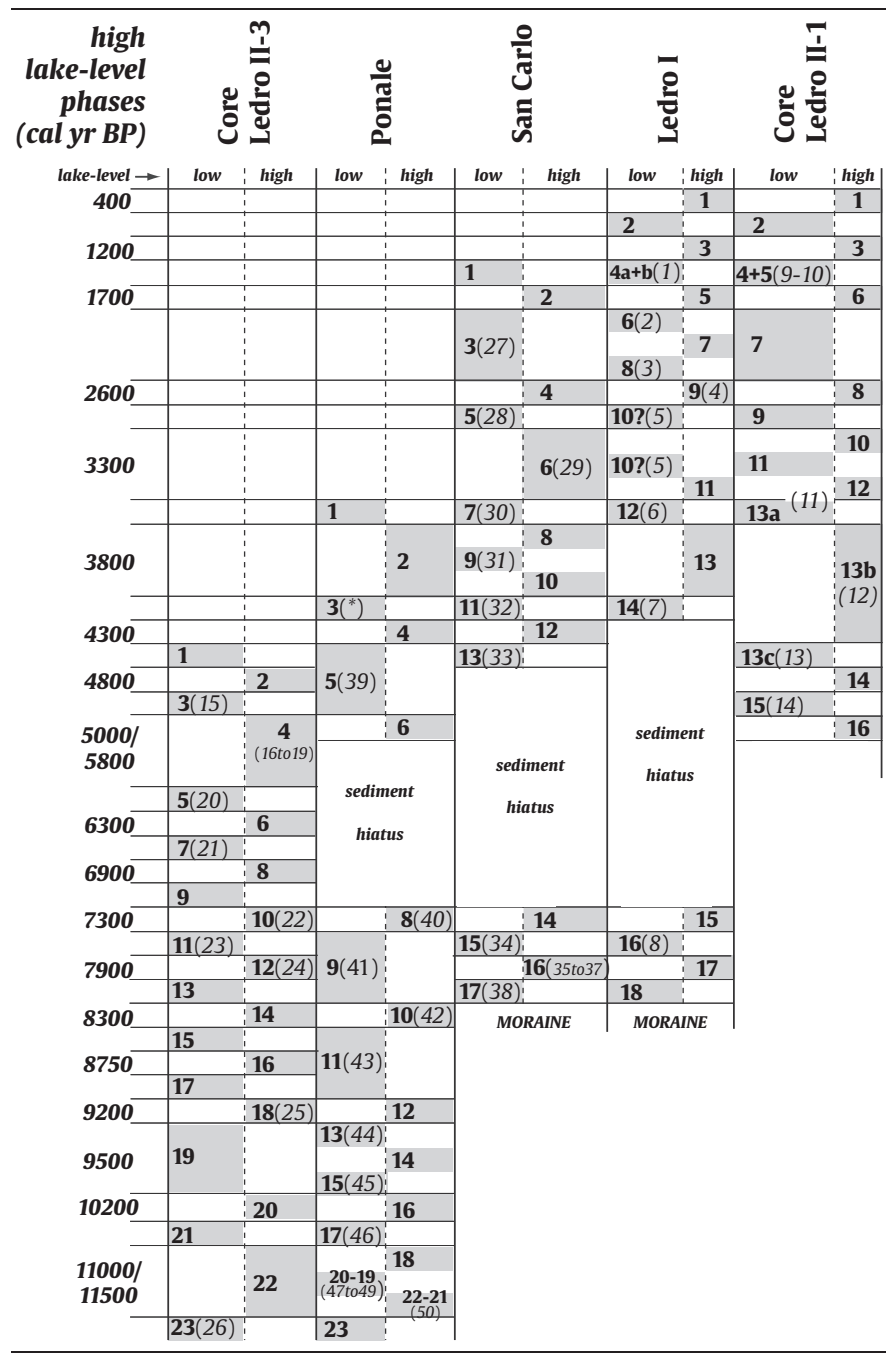

consequently, of the lake-level fluctuation magnitude were based on two references as follows:

First, the lithology and the composition of sediment: modern analogue studies in carbonate lakes (Magny, 1992, 1998, 2004, 2006) have shown that peat deposits correspond to overgrowing processes (shore area), while oncolites dominate more particularly in the shallow water of nearshore areas (ca. 0-0.5 m water depth), CF concretions correspond to at least ca. $0.5-1 \mathrm{~m}$ water depth, plate concretions ca. 1-1.5 m water depth, and tube concretions ca. 1.5-2 m water depth.

Secondly, the absolute elevation at which the main sedimentological and lithological markers have been observed in the sediment profiles. In addition, the sediment hiatuses and the erosion surfaces recognised in the different sites provide key indications about the elevation of the upper limit of sediment accumulation and, consequently, the possible position of the water table (Digerfeldt, 1986, 1988).

Of particular interest is the fact that the five sites studied in the littoral zone of Lake Ledro are located at different absolute elevations with different sensitivity to lake-level changes (Fig. 1, panel B; Fig. 5). Thus, they offer complementary lake-level data that either (1) overlap and 


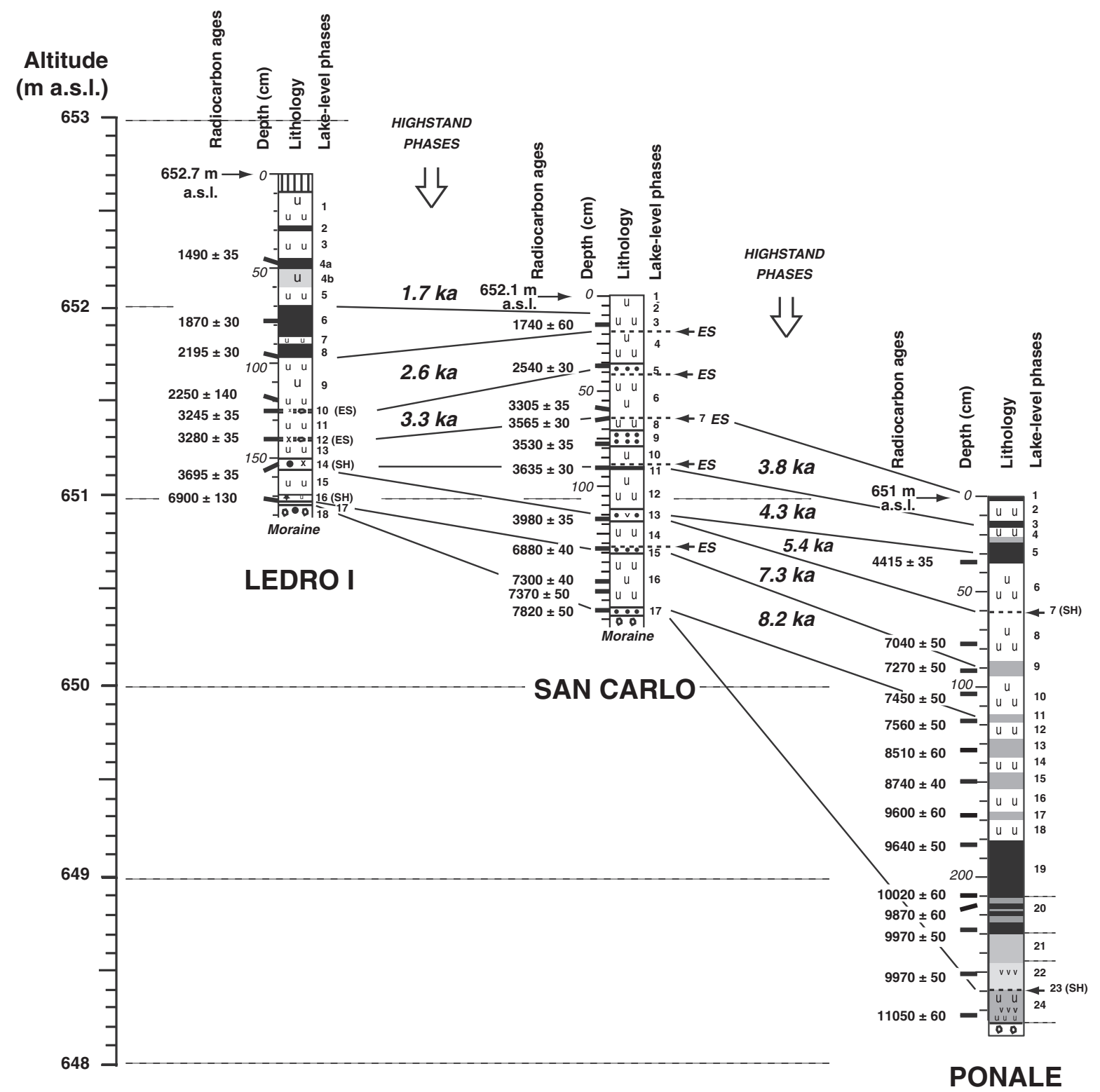

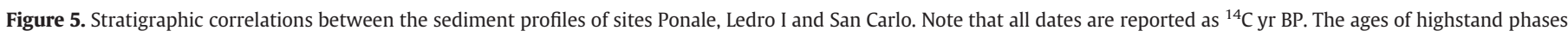
expressed in ka correspond to cal ka BP.

allow observation of lateral variations in the sediment facies, informative for the reconstruction of water depth in the past deposition environments, or (2) take over from each other when a period corresponding to a sediment hiatus in one profile is well-documented by deposits accumulated within another. This combination of five sediment profiles (Fig. 1, panel C; Fig. 5) also allows a better recognition of lateral variations in lithofacies and an absolute estimation of past lakelevel fluctuations to be developed.

Thus, as illustrated by Figure 6, the synthetic lake-level curve is a composite record. The early Holocene from 11,700 to 8000 cal yr BP is best documented by site Ponale, the mid-Holocene from 8000 to 4700 cal yr BP by core Ledro II-3, and the late Holocene from 4700 to 2250 cal yr BP by site San Carlo, and from 2250 cal yr BP to present by site Ledro I. On the basis of this synthetic record, it is possible to recognise both millennial-scale trends and centennial-scale events within the Holocene history of Lake Ledro.

On a millennial scale, two major periods may be distinguished as follows:
The period 11,700-4500 cal yr BP was characterized by a relatively low mean water table, interrupted by two major rises around 8200 and $7300-7100 \mathrm{cal}$ yr BP. The general lower lake-level average is clearly reflected by an absence of sedimentation and important sediment hiatuses affecting the sediment sequences of sites San Carlo and Ledro I. At site San Carlo, the basal morainic deposits are directly overlain by layers of carbonate lake-marl accumulated during the 8200 and 7300-7100 cal yr BP rise events (lake-level phases 16 and 14). At site Ledro I, located at an elevation slightly higher than that of the San Carlo profile (Fig. 5), the fingerprints of these two rise events appear to be less developed (phases 17 and 15), and they also directly overlie basal morainic deposits. The intermediate lowstand is marked by the deposition of a very thin sediment layer (only $2 \mathrm{~cm}$ ) on the site of Ledro I (phase 16). This suggests that the water table was most often below $651 \mathrm{~m}$ a.s.l. during this lowstand phase.

The period from 4500 cal yr BP to the present corresponds to a higher lake-level average following an abrupt rise in the water table 
Time (cal ka BP)

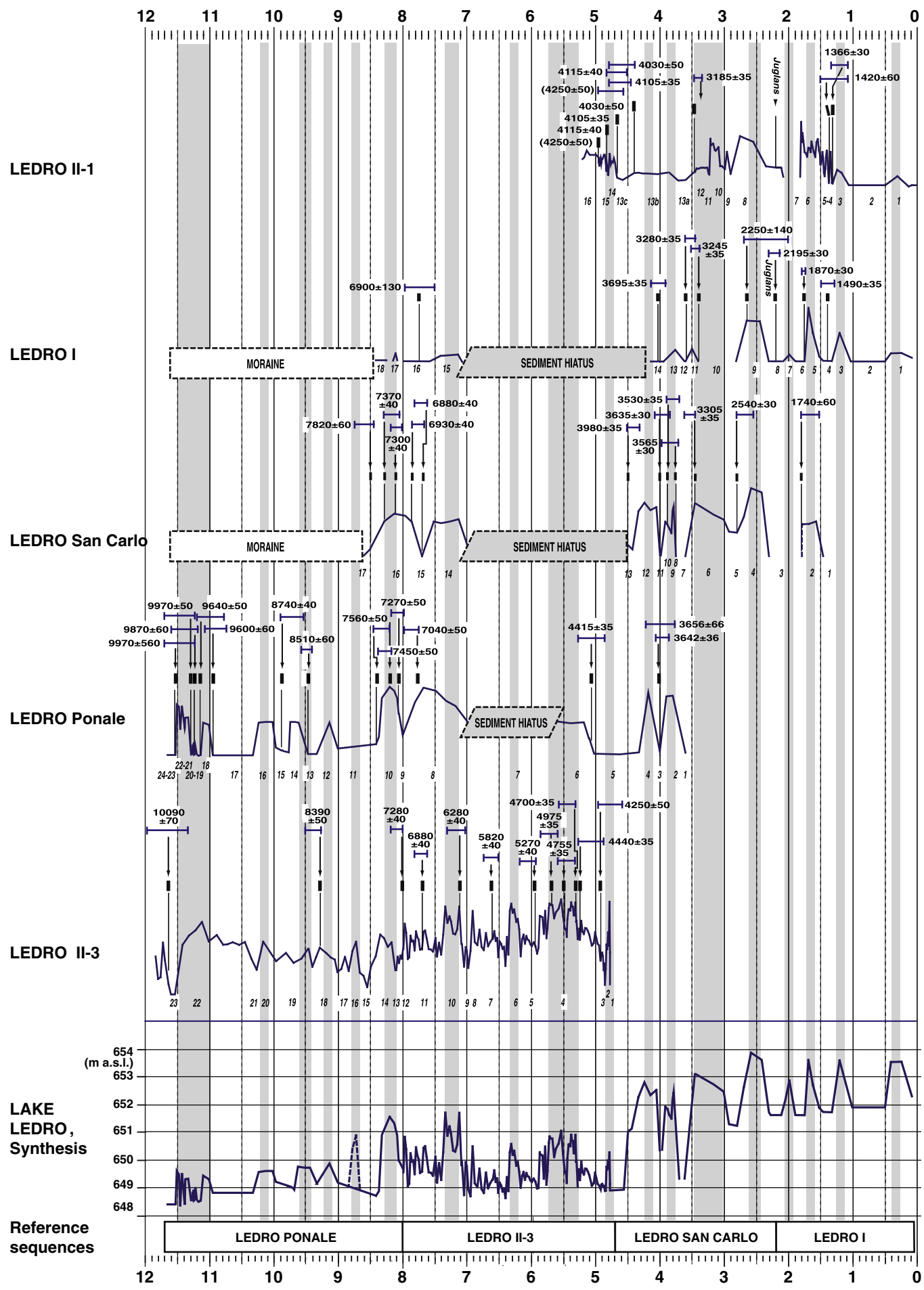

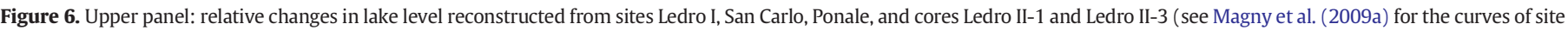

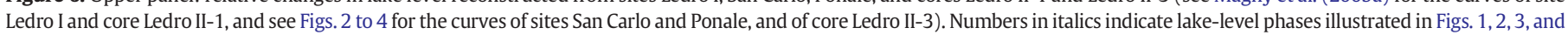

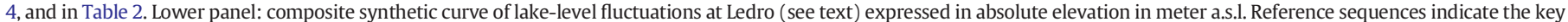

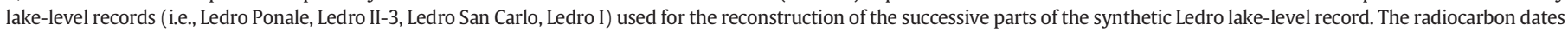
are indicated in ${ }^{14} \mathrm{C}$ yr BP with their corresponding calibrated ages at two sigma.

around 4500 cal yr BP. While core Ledro II-1 (phase 13b) did not highlight such a marked event (probably due to lateral variations in lithofacies; Magny et al., 2009a), this event is well evidenced by a return to a continuous sediment accumulation above $651 \mathrm{~m}$ a.s.l. (Fig. 5) at site San Carlo around 4500 cal yr BP (phases 13 and 12) and at site Ledro I around $4000 \mathrm{cal} \mathrm{yr} \mathrm{BP}$ (phases 14 and 13). As suggested by differences in pollen preservation observed at site Ledro I (Magny et al., 2009a), the range of lake-level fluctuations during the period $4600-2800 \mathrm{cal}$ yr BP has reached a mean elevation lower than during the period from $2800 \mathrm{cal}$ yr BP onwards. The age of phase 3 in the Ledro I and Ledro II-1 sediment sequences has been fixed at approximately $1200-1000$ cal yr BP by reference to 
the radiocarbon ages obtained for the immediately preceding phases 4 and 4-5 (Fig. 6; Table 2). Finally, the most recent highstand shown by the Ledro I and Ledro II-1 sediment profiles (i. e., phase 1 ) is assumed to be contemporaneous with the Little Ice Age (around 400-200 cal yr BP), in agreement with other regional lake-level records (Magny et al., 2009a).

On a centennial scale, site Ponale offers a sediment sequence with high temporal resolution and marked changes in the lithofacies to recognise lake-level events punctuating the early Holocene. The interval 11,500-11,000 cal yr BP appears to have been particularly complex with multiple highstands interrupted by lowering episodes. Additional phases of higher lake level appear at ca. 10,200, 9500 and 9150 cal yr BP in general agreement with those observed from core Ledro II-3 (Fig. 4). However, this later site gives evidence of a well-marked rise event around $8700 \mathrm{cal} \mathrm{yr} \mathrm{BP}$, which has been added to the synthetic lake-level record (Fig. 6, dotted line). The rise events around 8200 and $7300-7100$ cal yr BP are characterized by a sediment limit above $650 \mathrm{~m}$ a.s.l. as shown by the Ponale and San Carlo sediment profiles, and close to $651 \mathrm{~m}$ a.s.l. at Ledro I sediment profile (Fig. 5); this suggests a magnitude clearly larger than that of the events punctuating the preceding early Holocene and the following mid-Holocene periods. Core Ledro II-3 offers a high temporal resolution to document the mid-Holocene affected by sediment hiatuses at sites Ledro I, San Carlo, and also partly at site Ponale. It highlights major rises around 7300-7100 and 6300 cal yr BP, and around 5850-5350 cal yr BP, the latter also partly registered at site Ponale (phase 6). Finally, the sediment profiles of sites San Carlo and Ledro I allow the identification of major rise events at ca. $4300-3800,3300,2600,1700,1200$, and 400 cal yr BP.

\section{Discussion}

Lake-level changes are driven by climatic parameters affecting both evaporation and precipitation, but they can also be induced by a variety of local non-climatic factors including geomorphological phenomena, as well as human impact on the vegetation cover and the hydrology of the catchment. However, the comparison of lakelevel records may give evidence of synchronous lake-level changes within an area assumed to be climatically driven (Digerfeldt, 1988; Harrison and Digerfeldt, 1993; Magny, 1998, 2004). To assess this, Figure 7 presents a comparison between the Ledro lake-level record with that reconstructed at Lake Accesa in Tuscany, north-central Italy (Magny et al., 2007). Both the records benefit from good chronological control, and they are based on the same method of reconstruction. On a millennial scale, differences and similarities appear between the two lake-level records. Regarding the differences, the phase of relative high lake-level conditions at Accesa for the early Holocene from 11,600 to $9200 \mathrm{cal}$ yr BP does not find any equivalent in the Ledro record. This may reflect (1) the influence of a rocky threshold formed by the substratum, and/or (2) the peculiar conditions of the outlet area of Lake Ledro, which was occupied by a morainic dam during the last glacial maximum (Castellarin et al., 2005). At the deglaciation, the dam was incised as a result of the lowering of the regional base level of erosion. In contrast, the Accesa region has never been glaciated. Regarding the similarities, both the Ledro and Accesa records give evidence of (1) an abrupt rise in lake level around 4500 cal yr BP, which resulted in a water table at an elevation never reached before during the Holocene, and (2) higher lake-level average from ca. 2800 cal yr BP onwards.

The general pattern of palaeohydrological changes observed at Lakes Accesa and Ledro for the Holocene fully supports the interrogation by Tzedakis (2007) concerning the notion of an accentuated summer rain regime in the northern Mediterranean borderlands during the boreal insolation maximum. Given that sedimentological markers (i.e., carbonate concretions) used for the lake-level reconstruction form during the summer season, the generally lower water table observed at Lake Ledro during the early and mid-Holocene periods suggests that relatively dry summer conditions prevailed over the first half of the Holocene in northern Italy. This is also in agreement with the tripartite palaeohydrological pattern observed for the Holocene in western Europe from Scandinavia to the Mediterranean (Magny et al., 2003). However, the interpretation of isotopic data obtained at Lake Frassino by Baroni et al. (2006) does not agree with this general reconstruction and suggests that the late Holocene was characterized in northern Italy by generally drier climate conditions than during the mid Holocene. Moreover, stalagmite data from Corchia in north-central Italy suggest enhanced rainfall in the western Mediterranean during the deposition of sapropel 1 (Zanchetta et al., 2007). Such apparent discrepancies between the lake-level and isotopic records (i.e., different proxies used for the reconstructions) may reflect processes linked to the seasonality as illustrated by Peyron et al. (2011) and Magny et al. (2011). Thus, questions remain open and further lake-level investigations are needed for a precise reconstruction of the Holocene palaeohydrological history in the central Mediterranean, while multi-proxy studies are clearly needed for a better reconstruction and understanding of seasonality.

In addition, both the Ledro and Accesa records emphasize the importance of the period around $4500 \mathrm{cal}$ yr BP in the general climatic evolution of the Holocene. The millennial trend from generally low lake-level conditions during the early-mid Holocene towards a relatively high lake-level average during the late Holocene reconstructed at Lakes Ledro and Accesa reflects a common forcing factor, i.e. orbitally-driven induced changes in summer insolation. However, the abrupt rise in lake levels around 4500 cal yr BP points to the crucial impact of the climatic oscillation around 4500-4000 cal yr BP (Marchant and Hooghiemstra, 2004; Booth et al., 2005; Magny et al., 2009b; Giraudi et al., 2011) in the northwestern Mediterranean area. In the case of Lake Ledro, the marked rise in lake level around 4500 cal yr BP may have been accentuated by human impact due to early and middle Bronze age settlements. Thus, it is possible that wetter climatic conditions in combination with forest clearances have induced increasing erosion in the catchment area and, more particularly, may have been responsible for an accumulation of colluvial deposits in the outlet area with, as a result, an amplification of the response of the water table to the $4500 \mathrm{cal}$ yr BP climate reversal. In south-central Italy, at Lakes Mezzano and Albano, marked environmental changes were also observed around 4000-3800 cal yr BP in pollen and diatom assemblages (Ramrath et al., 2000; Sadori et al., 2004) as well as in sediment markers (Ramrath et al., 1999; Ariztegui et al., 2001). As discussed by Zhao et al. (2010) and illustrated by Figure 7, the climatic oscillation around $4500-4000$ cal yr BP may reflect a non-linear response of the climate system to the gradual decrease of insolation, in addition to key seasonal and inter-hemispherical changes in insolation. This orbital forcing was associated to a reorganisation of the general atmospheric circulation, with a southward shift of the ITCZ in the Tropics (Haug et al., 2001) and also possibly of westerlies affecting the mid-European latitudes and the northwestern Mediterranean. Figure 8 gives evidence of a strong impact of the climatic oscillation around 4500-4000 cal yr BP around the Mediterranean area and the contrasting palaeohydrological patterns associated to this event, with wetter conditions in the northwestern Mediterranean area as in west-central Europe (Magny et al., 2011), and drier conditions in the southwestern and eastern Mediterranean as in northern Tchad (Kröpelin et al., 2008).

On a centennial scale, Figure 7 shows a comparison of the successive highstands and lowstands which punctuated the entire Holocene period at Ledro with the same types of events recognised (1) in north-central Italy at Lake Accesa (Magny et al., 2007) and (2) in west-central Europe north of the Alps (Magny, 2004, 2006). Keeping in mind the radiocarbon-age uncertainty, the three lake-level records suggests generally similar patterns of changes with major highstands at ca. 11,200-11,100, 10,200, 9500-9000, 8200, 7300, 6200, $5700-5300,4800,4500-3800,3300,2600,1200$, and 400 cal yr BP. 


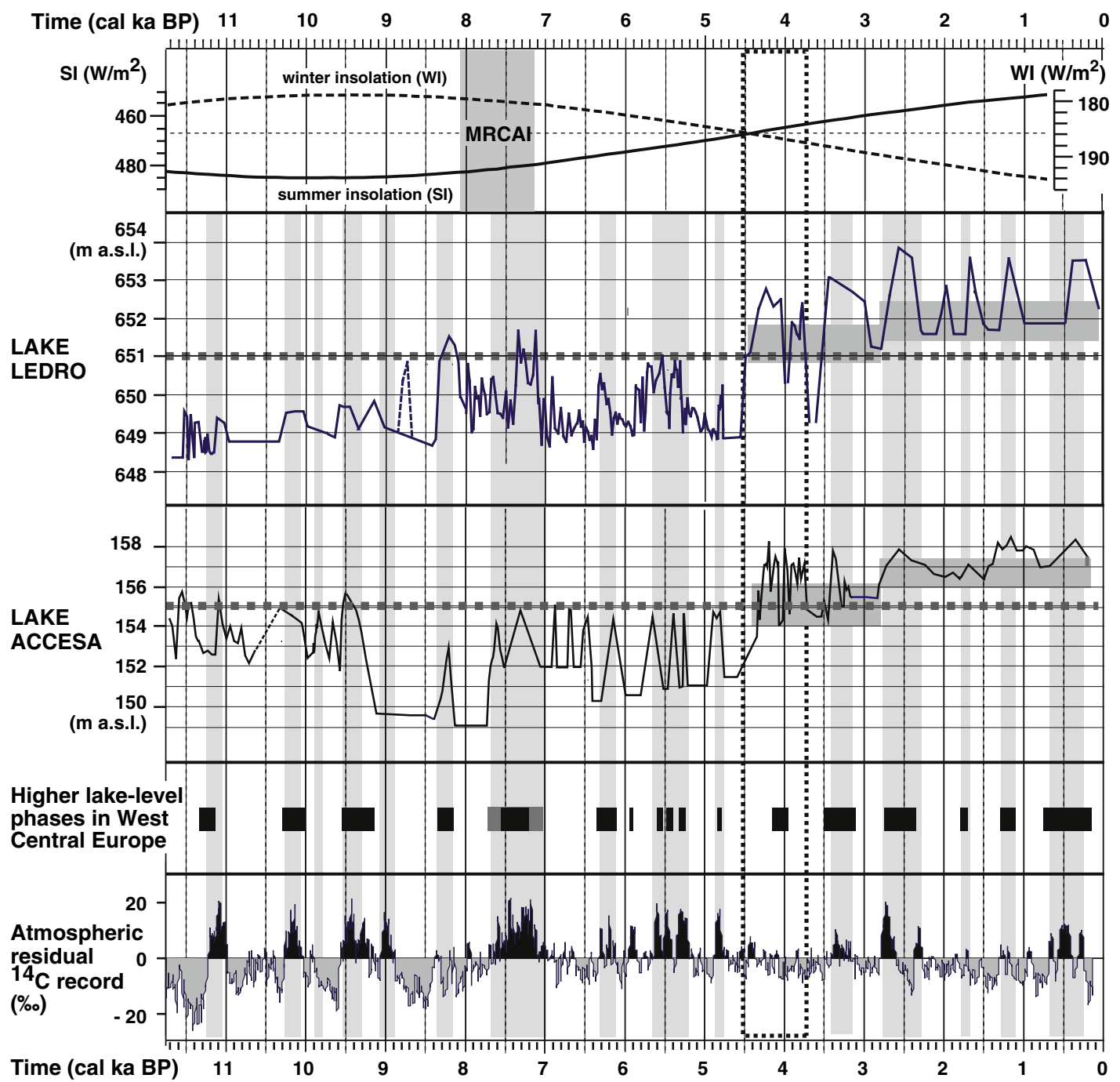

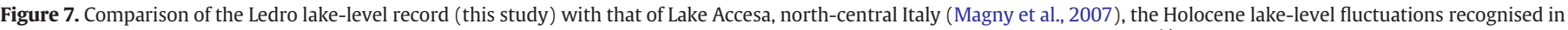

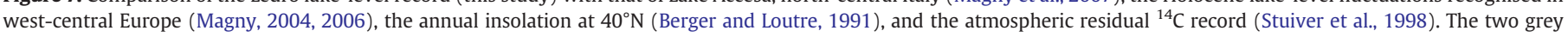

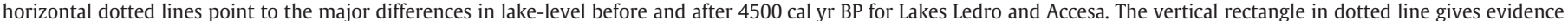

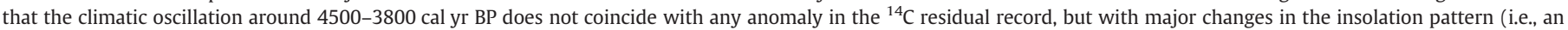
important reorganisation in seasonality). MRCAI: Period of maximal rate of change in annual insolation (Zhao et al., 2010). SI: summer insolation, WI: winter insolation.

As shown in west-central Europe and illustrated by Figure 7 in comparison with the atmospheric ${ }^{14} \mathrm{C}$ residual record (Stuiver et al., 1998), the changes were probably responses to cooling events induced by (1) the final steps of the deglaciation in the North Atlantic area such as the Preboreal oscillation, the $9.3 \mathrm{ka}$ and $8.2 \mathrm{ka}$ events (Magny and Bégeot, 2004; Fleitman et al., 2008; Yu et al., 2010), and (2) variations in solar activity (Björck et al., 2001; Magny, 2004). The late Holocene at Ledro shows strong similarities with paleohydrological changes recognised at Lakes Fucino (Giraudi, 1998) and Mezzano (Giraudi, 2004) as well on the higher Apennine massifs (Giraudi, 2005) and in the Ombrone river delta (Bellotti et al., 2004). As an additional comment for this later period, it is worth noting that the Ledro record confirms the complexity of the tripartite climatic event around 4300-3800 cal yr BP in the central Mediterranean as discussed by Magny et al. (2009b).

Regarding the early Holocene, the Ledro record suggests another possible complex climatic oscillation around 11,500-11,000 cal yr BP, i.e. at the time of the Preboreal oscillation (Björck et al., 1997). This complexity echoes that observed for the same time window at Lake Accesa and, as a working hypothesis, may have resulted from different successive forcing factors (deglaciation and solar activity) as discussed by van der Plicht et al. (2004) and Bos et al. (2007).

The rises around 8200, 7300-7100, and 5800-5300 cal yr BP appear to be the most prominent events in the early to mid-Holocene at Lake Ledro. The lake-level and the pollen data collected at Ledro suggest that the $8.2 \mathrm{kyr}$ event may have had a key impact on the regional vegetation. As pointed out in the Results section, Figure 3 shows how the rise events at ca. 11,100,10,200, and 9500 cal yr BP coincided with successive small peaks of Picea and Abies. The rise event broadly synchronous with the $8.2 \mathrm{ka}$ event corresponded to a strong expansion of Picea and to the starting expansion of Abies, probably favoured by increasing moisture. Finally, the strong development of Abies coincided with the rise event dated to $7300-7100$ cal yr BP. This major event is also observed at Lake Accesa where it marks the end of the lake-level minimum dated to 9200-7700 cal yr BP (Magny et al., 2007). In marine core MD90-917 in the Adriatic Sea, Siani et al. (2010) have shown that the Holocene SST record was punctuated by two major negative anomalies at 8200 and around $7000 \mathrm{cal}$ yr BP. This event may have had a more widespread significance as suggested by (1) a near cessation of the early to mid-Holocene sea-level rise (Bird 
Lake-level $(\mathrm{m})$ at Cerin, Jura Mountains (eastern France, $45^{\circ} \mathrm{N}$ )

Lake-level (m) at Ledro, northern Italy $\left(45^{\circ} \mathrm{N}\right)$

cal ka BP

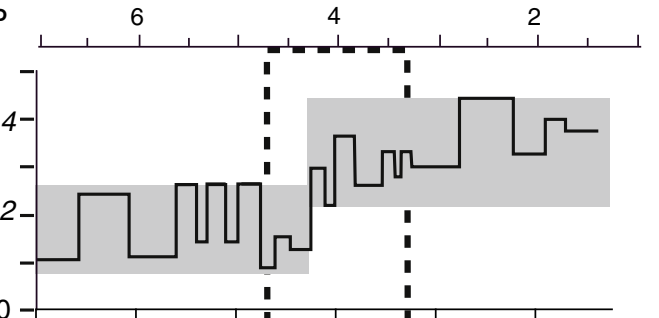

1

Lake-level (m)

at Accesa,

central Italy $\left(42^{\circ} \mathrm{N}\right)$

\section{Lake-level \\ at Preola, \\ Soreq Cave, Israël (Precipitation, $\mathrm{mm} /$ year, $31^{\circ} \mathrm{N}$ )}

Sicily (south Italy, $37^{\circ} \mathrm{N}$ ) ভ

Lake Yoa, northern Chad, $19^{\circ} \mathrm{N}$ (water conductivity)

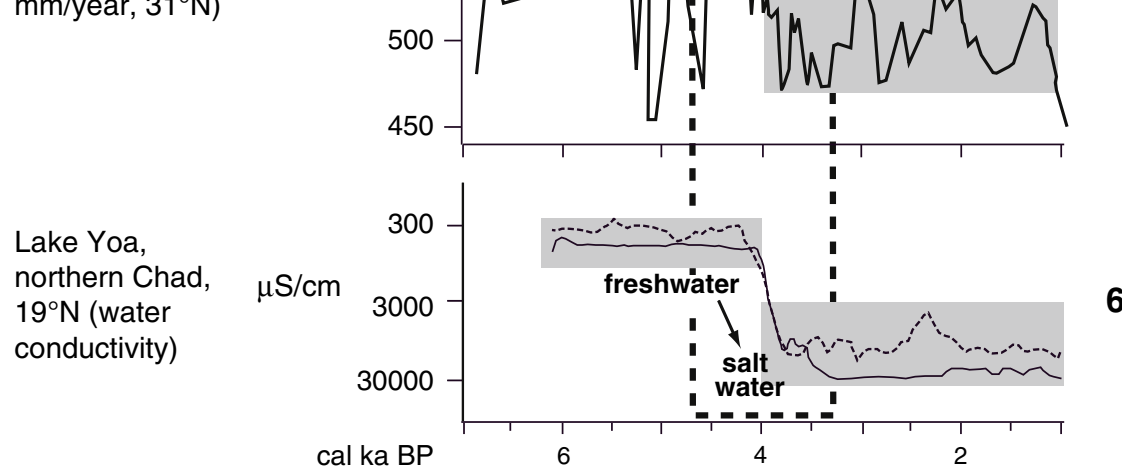

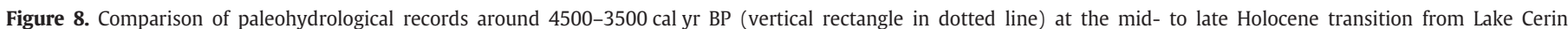

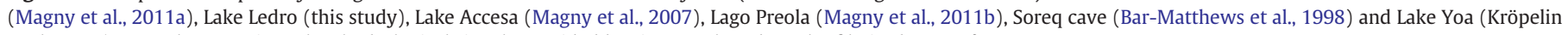
et al., 2008). Note the opposite palaeohydrological signals provided by sites north and south of latitude ca. $40^{\circ} \mathrm{N}$.

et al., 2010), (2) a major IRD peak in the North Atlantic (Bond et al., 2001), and (3) an expansion of polar water in the Nordic Seas (Rasmussen and Thompsen, 2010). The interval 8000-7000 cal yr BP also appears to be synchronous with the highest rate of change in annual insolation for the Holocene (Fig. 7; Zhao et al., 2010), while a prolonged period of decrease in the residual atmospheric radiocarbon developed between 8500 and 7200 cal yr BP (Fig. 7; Stuiver et al., 1998). Thus, the 7500-7000 cal yr BP event may have been driven by a combination of orbital forcing and change in solar activity. Finally, the rise event dated to 5850-5300 cal yr BP at Lake Ledro coincided 
with a major worldwide cooling event (Mayewski et al., 2004) at the beginning of the Neoglacial (Magny et al., 2004).

\section{Conclusions}

On the basis of a specific sedimentological approach, this paper aims at establishing a lake-level record for the Holocene at Lake Ledro (Trentino, northeastern Italy). The chronology is derived from 51 radiocarbon dates. The reconstruction of the lake-level record combines data from five sediment profiles sampled in distinct locations in the lake's littoral zone.

- On a millennial scale, two successive periods may be distinguished. The first, between 11,700 and 4500 cal yr BP, was characterized by lower average lake level, and the second by a higher mean water table. The first period was interrupted by two major rise events around 8200 and 7300-7100 cal yr BP.

- The major climatic oscillation marked, at Ledro by an abrupt rise at 4500 cal yr BP, may be related to (1) key seasonal and interhemispherical changes in insolation, and (2) to a non-linear response of the climate system to the orbitally-driven gradual decrease in insolation.

- In agreement with the lake-level record at Accesa in north-central Italy, the results obtained at Lake Ledro suggest that relatively dry summer conditions prevailed during the early to mid-Holocene periods in northern Italy. This questions the notion of an accentuated summer rain regime in the northern Mediterranean borderlands during the boreal insolation maximum.

- On a centennial scale, the Ledro record indicates that the entire Holocene was punctuated by century-scale highstands. Correlations with the Preboreal oscillation and the $8.2 \mathrm{ka}$ event as well as comparisons with the atmospheric ${ }^{14} \mathrm{C}$ residual record suggest that these short-lived variations in lake-level developed at Ledro in response to (1) the final steps of the deglaciation in the North Atlantic area, and (2) variations in solar activity.

Finally, the expansion of Picea and Abies around 8200 and 7300 cal yr BP respectively may have been favoured by climatic changes towards wetter conditions.

\section{Acknowledgments}

Financial support for this study was provided by the French ANR (project LAMA, M. Magny and N. Combourieu-Nebout), as well as the Ecole Française de Rome. The authors also express their sincere thanks to J. Olsen for his help with the English language, and to J. Didier, A. Stock, N. Degasperi, M. Grosso, I. Bettinardi, S. Frisia, and M.L. Philippi, for their help in the field work. Thorough reviews and constructive comments by two anonymous referees and by Kenneth Adams, Associate Editor, greatly helped to improve the manuscript.

\section{References}

Ariztegui, D., Chondrogianni, C., Lami, A., Guilizzoni, P., Lafargue, E., 2001. Lacustrine organic matter and the Holocene paleoenvironmental record of Lake Albano (central Italy). Journal of Paleolimnology 26, 283-292.

Bar-Matthews, M., Ayalon, A., Kaufman, A., 1998. Middle to Late Holocene (6500 yr period) paleoclimate in the eastern Mediterranean region from stable isotopic composition of speleothems from Soreq Cave, Israël. In: Issar, A., Brown, N. (Eds.) Environment and society in times of climate change. Kluwer Academic, Dordrecht, pp. 203-214.

Baroni, C., Zanchetta, G., Fallick, A.E., Longinelli, A., 2006. Molluscs stable isotope record of a core from Lake Frassino (northern Italy): hydrological and climatic changes during the last $14 \mathrm{ka}$. The Holocene 16, 827-837.

Bellotti, P., Caputo, C., Davoli, L., Evangelista, S., Garzanti, E., Pugliese, F., Valeri, P., 2004. Morpho-sedimentary characteristics and Holocene evolution of the emergent part of the Ombrone River delta (southern Tuscany). Geomorphology 61, 71-90.

Battaglia, R., 1943. La palafitta del Lago di Ledro nel Trentino. Memoria del Museo di Storia Naturale della Venezia Tridentina 7, 1-63.

Berger, A., Loutre, M.F., 1991. Insolation values for the climate of the last 10 million years. Quaternary Science Reviews 10, 297-317.
Beug, H.J., 1964. Untersuchungen zur spätglazialen Vegetationsgeschichte im Gardaseegebiet unter besonderer Berücksichtigung der mediterranen Arten. Flora 154, 401-444.

Bird, M., Austin, W.E.N., Wurster, C.M., Fifield, L.K., Mojtahid, M., Sargeant, C., 2010. Punctuated eustatic sea-level rise in the early mid-Holocene. Geology 38, 803-806.

Björck, S., Muscheler, R., Kromer, B., Andresen, C.S., Heinemeier, J., Johnsen, S., Conley, D., Koç, N., Spurk, M., Veski, S., 2001. High-resolution analyses of an early Holocene climate event may imply decreased solar forcing as an important climate trigger. Geology 29, 1107-1110.

Björck, S., Rundgren, M., Ingolfsson, O., Funder, S., 1997. The Preboreal oscillation around the Nordic seas: terrestrial and lacustrine responses. Journal of Quaternary Science $12,455-465$.

Bond, G., Kromer, B., Beer, J., Muscheler, R., Evans, M.N., Showers, W., Hoffmann, S., Lotti-Bond, R., Hajdas, I., Bonani, G., 2001. Persistent solar influence on North Atlantic climate during the Holocene. Science 294, 2130-2136.

Booth, R., Jackson, S.T., Forman, S.L., Kutzbach, J.E., Bettis, E.E., Kreig, J., Wright, D.K., 2005. A severe centennial-scale drought in mid-continental North America 4200 years ago and apparent global linkages. The Holocene 15, 321-328.

Bos, J.A.A., van Geel, B., van der Plicht, J., Bohncke, S.J.P., 2007. Preboreal climate oscillations in Europe: wiggle-match dating and synthesis of Dutch high-resolution multi-proxy records. Quaternary Science Reviews 26, 1927-1950.

Castellarin, A., Picotti, V., Cantelli, L., Claps, M., Trombetta, L., Selli, L., Carton, A., Borsato, A., Daminato, F., Nardin, M., Santuliana, E., Veronese, L., Bollettinari, G., 2005. Riva del Garda. Note illustrative della carta geologica d'Italia alla scale 1:50 000. Foglio 080. Provincia Autonoma di Trento, L.A.C. Firenze.

Digerfeldt, G., 1986. Studies on past lake-level fluctuations. In: Berglund, B.E. (Ed.), 1986. John Wiley and Sons, Handbook of Holocene Palaeoecology and Palaeohydrology, pp. 127-143.

Digerfeldt, G., 1988. Reconstruction and regional correlation of Holocene lake-level fluctuations in lake Bysjön, South Sweden. Boreas 17, 165-182.

Digerfeldt, G., Sandgren, P., Olsson, S., 2007. Reconstruction of Holocene lake-level changes at Lake Xinias, central Greece. The Holocene 17, 361-367.

Eastwood, W.J., Leng, M.J., Roberts, N., Davis, B., 2007. Holocene climate change in the eastern Mediterranean region: a comparison of stable isotope and pollen data from Lake Gölhisar, southwest Turkey. Journal of Quaternary Science 22, 327-341.

Faegri, K., Iversen, J., 1989. Textbook of Pollen Analysis, 4th edition. John Wiley \& Sons.

Giraudi, C., 1998. Late Pleistocene and Holocene lake-level variations in Fucino Lake (Abruzzo, central Italy) inferred from geological, archaeological and historical data. In: Harrison, S.P., Frenzel, B., Huckried, U., Weiss, M. (Eds), Palaeohydrology as reflected in lake-level changes as climatic evidence for Holocene times. Paläoklimaforschung 25 , pp 1-17.

Giraudi, C., 2004. Le oscillazioni di livello del Lago di Mezzano (Valentino-VT): variazioni climatiche e interventi antropici. Il Quaternario 17, 221-230.

Giraudi, C., 2005. Middle to Late Holocene glacial variations, periglacial processes and alluvial sedimentation on the higher Apennine massifs (Italy). Quaternary Research 64, $176-184$.

Giraudi, C., Magny, M., Zanchetta, G., Drysdale, R.N., 2011. The Holocene climatic evolution of the Medtirreanean Italy: a review of the geological continental data. The Holocene.

Harrison, S.P., Digerfeldt, G., 1993. European lakes as palaeohydrological and palaeoclimatic indicators. Quaternary Science Reviews 12, 233-248.

Haug, G.H., Hughen, K.A., Sigman, D.M., Peterson, L.C., Röhl, U., 2001. Southward migration of the Intertropical Convergence Zone through the Holocene. Science 293, 1304-1308.

Kröpelin, S., Verschuren, D., Lézine, A.M., Eggermont, H., Cocquyt, C., Francus, P., Cazet, J.P., Fagot, M., Rumes, B., Russell, J.M., Darius, F., Conley, D.J., Schuster, M., von Suchodoletz, H., Engstrom, D.R., 2008. Climate-driven ecosystem succession in the Sahara: the past 6000 years. Science 320, 765-768.

Magny, M., 1992. Holocene lake-level fluctuations in Jura and the northern subalpine ranges, France: regional pattern and climatic implications. Boreas 21, 319-334.

Magny, M., 1998. Reconstruction of Holocene lake-level changes in the Jura (France): methods and results. Paläoklimaforschung 25, 67-85.

Magny, M., 2004. Holocene climatic variability as reflected by mid-European lake-level fluctuations, and its probable impact on prehistoric human settlements. Quaternary International 113, 65-79.

Magny, M., 2006. Holocene fluctuations of lake levels in west-central Europe: methods of reconstruction, regional pattern, palaeoclimatic significance and forcing factors. Encyclopedia of Quaternary Geology, Elsevier. 1389-1399.

Magny, M., de Beaulieu, J.L., Drescher-Schneider, R., Vannière, B., Walter-Simonnet, A.V., Miras, Y., Millet, L., Bossuet, G., Peyron, O., Brugiapaglia, E., Leroux, A., 2007. Holocene climate changes in the central Mediterranean as recorded by lake-level fluctuations at Lake Accesa (Tuscany, Italy). Quaternary Science Reviews 26, 1736-1758.

Magny, M., Bégeot, C., 2004. Hydrological changes in the European midlatitudes associated with freshwater outbursts from Lake Agassiz during the Younger Dryas event and the early Holocene. Quaternary Research 61, 181-192.

Magny, M., Bégeot, C., Guiot, J., Peyron, O., 2003. Contrasting patterns of hydrological changes in Europe in response to Holocene climate cooling phases. Quaternary Science Reviews 22, 1589-1596.

Magny, M., Bossuet, G., Ruffaldi, P., Leroux, A., Mouthon, J., 2011a. Orbital imprint on Holocene palaeohydrological variations in west-central Europe as reflected by lake-level changes at Cerin (Jura Mountains, eastern France). Journal of Quaternary Science DOI:. doi:10.1002/jqs.1436.

Magny, M., Galop, D., Bellintani, P., Desmet, M., Didier, J., Haas, J.N., Martinelli, N., Pedrotti, A., Scandolari, R., Stock, A., Vannière, B., 2009a. Late-Holocene climatic variability south of the Alps as recorded by lake-level fluctuations at Lake Ledro, Trentino, Italy. The Holocene 19, 575-589.

Magny, M., Peyron, O., Sadori, L., Ortu, E., Zanchetta, G., Vannière, B., Tinner, W., 2011b. Contrasting patterns of precipitation seasonality during the Holocene in the south- 
and north-central Mediterranean. Journal of Quaternary Science DOI:. doi:10.1002/ jqs.1543.

Magny, M., Vannière, B., Zanchetta, G., Fouache, E., Touchais, G., Petrika, L., Coussot, C., Walter-Simonnet, A.V., Arnaud, F., 2009b. Possible complexity of the climatic event around $4300-3800 \mathrm{cal} \mathrm{BP}$ in the central and western Mediterranean. The Holocene $19,823-833$.

Marchant, R., Hooghiemstra, H., 2004. Rapid environmental change in African and South American tropics around 4000 years before present: a review. Earth Science Reviews 66, 217-260.

Mayewski, P.A., Rohling, E.E., Stager, J.C., Karlen, W., Maasch, K.A., Meeker, L.D., Meyerson, E.A., Gasse, F., van Kreveld, S., Holmgren, K., Lee-Thorp, J., Rosqvist, G., Rack, F., Staubwasser, M., Schneider, R.R., Steig, E.J., 2004. Holocene climate variability. Quaternary Research 62, 243-255.

Mitchum, R.M., Vail, J.R., Thompson, S., 1977. The depositional sequence as a basic unit for stratigraphic analysis. American Association Geolological Bulletin, Memory 26, 53-62.

Mouthon, J., 1984. Les mollusques. In: SRAE (Ed.), Les lacs de Clairvaux, Monographies écologiques. Service Régional d'Aménagement des Eaux Report, 67-75.

Peyron, O., Goring, S., Dormoy, I., Kotthoff, U., Pross, J., de Bealieu, J.L., Drescher-Schneider, R., Magny, M., 2011. Holocene seasonality changes in the central Mediterranean region reconstructed from the pollen sequences of Lake Accesa (Italy) and Tenaghi Philippon (Greece). The Holocene.

Ramrath, A., Nowaczyk, N., Negendank, J., 1999. Sedimentological evidence for environmental changes since 34,000 years BP from Lago di Mezzano, central Italy. Journal of Paleolimnology 21, 423-435.

Ramrath, A., Sadori, L., Negendank, J., 2000. Sediment from Lago di Mezzano, central Italy: a record of Lateglacial/Holocene climatic variations and anthropogenic impact. The Holocene 10, 87-95.

Rasmussen, T.L., Thompsen, E., 2010. Holocene temperature and salinity variability of the Atlantic Water inflow to the Nordic seas. The Holocene 8, 1223-1234.

Reed, J.M., Stevenson, A.C., Juggins, S., 2001. A multi-proxy record of Holocene climatic change in southwestern Spain: the Laguna di Medina, Cadiz. The Holocene 11, 707-719.

Reille, M., 1992-1998. Pollen et spores d'Europe et d'Afrique du nord. Laboratoire de Botanique Historique et Palynologie, Université d'Aix-Marseille, France.
Reimer, P., et al., 2004. IntCal04 terrestrial radiocarbon age calibration, 26-0 ka BP. Radiocarbon 46, 1029-1058.

Reisigl, H., 2001. Geologie. Institut für Botanik, Universität Innsbruck, Flora und Vegetation der Berge westlich des Gardasees. Führer zur Geobotanischen Bergwoche Val di Ledro. 39 pp.

Sadori, L., Narcisi, B., 2001. The postglacial record of environmental history from Lago di Pergusa, Sicily. The Holocene 11, 655-671.

Sadori, L., Giraudi, C., Petitti, P., Ramrath, A., 2004. Human impact at Lago di Mezzano (central Italy) during the Bronze Age: a multidisciplinary approach. Quaternary International 113, 5-17.

Siani, G., Paterne, M., Colin, C., 2010. Late Glacial to Holocene planktic foraminifera bioevents and climatic record in the South Adriatic Sea. Journal of Quaternary Science DOI:. doi:10.1002/jqs.1360.

Shotton, F.W., Blundell, D.J., Williams, R.E.G., 1968. Birmingham University radiocarbon dates II. Radiocarbon 10, 200-206.

Stuiver, M., Reimer, P.J., Bard, E., Beck, J.W., Burr, G.S., Hughen, K.A., Kromer, B., McCormac, G., van der Plicht, J., Spurk, M., 1998. Intcal98 radiocarbon age calibration, 24,000-0 cal BP. Radiocarbon 40, 1041-1083.

Tzedakis, P.C., 2007. Seven ambiguities in the Mediterranean palaeoenvironmental narrative. Quaternary Science Reviews 26, 2042-2066.

van der Plicht, J., van Geel, B., Bohncke, S.J.P., Bos, J.A.A., Blaauw, M., Speranza, A.O.M. Muscheler, R., Björck, S., 2004. The Preboreal climate reversal and a subsequent solar-forced climate shift. Journal of Quaternary Science 19, 263-269.

Yu, S.-Y., Colman, S.M., Lowell, T.V., Milne, G.A., Fisher, T.G., Breckenridge, A., Boyd, M., Teller, J.T., 2010. Freshwater outburst from Lake Superior as a trigger for the cold event 9300 years ago. Science 328, 1162-1266.

Zanchetta, G., Drysdale, R.N., Hellstrom, J.C., Fallick, A.E., Isola, I., Gagan, M.K., Pareschi, M.T., 2007. Enhanced rainfall in the western Mediterranean during deposition of sapropel 1: stalagmite evidence from Corchia cave (Central Italy). Quaternary Science Reviews 26, 279-286.

Zhao, C., Yu, Z., Zhao, Y., 2010. Holocene climate trend, variability, and shift documented by lacustrine stable-isotope record in the northeastern United States. Quaternary Science Reviews 29, 1831-1843.

Zolitschka, B., Wulf, S., Negendank, J.F.W., 2000. Circum-Mediterranean lake records as archives of climatic and human history. Quaternary International 73 (74), 1-5. 